\title{
A taxonomic review of the Rhinotermitidae (Isoptera) of Thailand
}

Yoko Takematsu $^{\mathrm{a} *}$ \& Charunee Vongkaluang ${ }^{\mathrm{b}}$

${ }^{a}$ Faculty of Agriculture, Yamaguchi University, Yamaguchi, Japan.

${ }^{b}$ Royal Forest Department, Bangkok, Thailand.

*Faculty of Agriculture, Yamaguchi University, 1677-1 Yoshida, Yamaguchi 753-8515, Japan. e-mail: takematu@yamaguchi-u.ac.jp 


\title{
A taxonomic review of the Rhinotermitidae (Isoptera) of Thailand
}

\author{
Ninety series of rhinotermitid termites were collected from 19 localities \\ distributed across much of Thailand, and compared with specimens \\ deposited in the NHML. Eleven species belonging to five genera of \\ Rhinotermitidae are recorded from Thailand. Three species of two genera, \\ Reticulitermes (R. assamensis) and Parrhinotermes $(P$. \\ microdentiformisoides and $P$. buttelreepeni), are new records from \\ Thailand. Keys to the genera and species based on the soldier caste are \\ given. Soldiers of all species are illustrated and morphological \\ measurements are given.
}

Keywords: Rhinotermitidae; soldier; key to genera and species; new record; Thailand.

\section{Introduction}

Three major publications have dealt with the taxonomy of the Thai termite fauna to date.

The termite fauna of Thailand had been poorly known before Ahmad's (1965) comprehensive publication. Ahmad (1965) recorded 9 species belonging to 3 genera of Rhinotermitidae, Coptotermes, Prorhinotermes and Schedorhinotermes, including 3 new species. After Ahmad (1965), Harris (1968) recorded 2 species of Coptotermes and 
Morimoto (1973) recorded 3 species of Coptotermes and 3 species of

Schedorhinotermes without new or newly recorded species. Until the present

publication, a total of 9 species belonging to 3 genera were known from Thailand.

During eight years of study, we have had the opportunity to collect from 19

localities distributed across much of the country. As a result, the Thai fauna is now

represented by 11 species of Rhinotermitidae.

\section{Material and methods}

\section{Material examined}

This study is based mainly on specimens collected by the authors and our colleagues

between 1996 and 2003. Sampling was done at 19 localities, including 13 conservation

forests. Specimens have been deposited in the Faculty of Agriculture, Yamaguchi

University, Japan [FAYU]. We also examined specimens collected by Ahmad and

Morimoto deposited in the Natural History Museum, London [NHML]. In the following

descriptions where institutions are not given, the specimens have been deposited in

FAYU. All collecting localities, including Ahmad's and Morimoto's collections, are

listed in Table 1 and Fig. 1. Thailand has 76 provinces which can be grouped into 5 
regions: North, Northeast, Central, East and South (Table 1 and Fig. 1). Unless

specified, the number of series (vial of a single sample of specimens) examined per

locality was one. Measurements are in $\mathrm{mm}$ with the mean in parenthesis.

[Table 1 near here]

[Figure 1 near here]

\section{Measurements and indices}

In this study 11 measurements (Fig.2) and 3 indices were used. Abbreviations of all measurements and indices are shown below. Measurements in parentheses are means.

Measurements

Head length without mandibles (HL).

Head width at base of mandibles (bHW).

Maximum width of head (mHW).

Left mandible length (LML).

Distance from tip of apical tooth to tip of the 1st marginal tooth on left mandible (DAM1).

Distance from tip of the 1st marginal tooth to tip of the 2 nd marginal tooth on left mandible (DM1M2). 
Pronotum length (PL).

Maximum width of pronotum (PW).

Postmentum length (PosL).

Maximum width of postmentum (PosW).

Number of antennal segments (A).

Indices

Head width at base of mandibles / maximum width of head (bHW/mHW).

Maximum width of head / head length without mandibles (mHW/HL)

Left mandible length / head length without mandibles (LML/HL).

Distance from tip of apical tooth to tip of the 1st marginal tooth on left mandible /

distance from tip of the 1 st marginal tooth to tip of the 2 nd marginal tooth on left

mandible (DAM1 / DM1M2).

[Figure 2 near here]

\section{Checklist of Rhinotermitidae in Thailand}

As a result of this study, the current species checklist is now as follows:

Coptotermes Wasmann, 1896

Coptotermes curvignathus Holmgren, 1913 
Coptotermes gestroi (Wasmann, 1896)

Coptotermes kalshoveni Kemner, 1934

Coptotermes premrasmi Ahmad, 1965

Parrhinotermes Holmgren, 1910 (new record)

Parrhinotermes buttelreepeni Holmgren, 1913 (new record)

Parrhinotermes microdentiformisoides Thapa, 1981 (new record)

Prorhinotermes Silvestri, 1909

Prorhinotermes flavus (Bugnion and Popoff, 1910)

Reticulitermes Holmgren, 1913 (new record)

Reticulitermes assamensis Gardner, 1944 (new record)

Schedorhinotermes Silvestri, 1909

Schedorhinotermes malaccensis (Holmgren, 1913)

Schedorhinotermes medioobscurus (Holmgren, 1914)

Schedorhinotermes rectangularis Ahmad, 1965

\section{Key to genera of Rhinotermitidae in Thailand based on soldier caste}

1. Mandibles without marginal tooth (Fig. 3E) ...................................................... 2

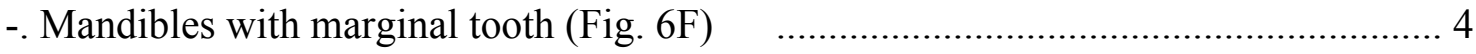


2. Fontanelle opening large, close to clypeus (Fig. 3A). Coptotermes Wasmann

-. Fontanelle small, located far behind clypeus 3

3. Head almost parallel sided, without eyes (Fig. 9A) Reticulitermes Holmgren

-. Head oval, distinctly narrowed anteriorly, with distinct eyes (Fig. $8 \mathrm{~A})$ Prorhinotermes Silvestri

4. Mandibles without serrations at inner base (Fig. 10E). Small eyes present. Soldiers dimorphic Schedorhinotermes Silvestri

-. Mandibles with very fine serrations at inner base (Fig. 6F). Eyes absent. Soldiers monomorphic Parrhinotermes Holmgren

\section{Descriptions by Y. Takematsu}

\section{Coptotermes Wasmann, 1896}

Type species: Coptotermes gestroi (Wasmann, 1896)

The genus is one of the most serious wood pests in the world. There are nearly 80 species recorded in the world and 60 species have been described from Oriental region. In Thailand, 5 species were recorded by Ahmad (1965).

Thirty of 60 Oriental species have been described from China between 1984 and 
1986 (Huang et al. 1989). However most of these 30 species names from China were erected based on slight differences of head size despite their wide intraspecific variation in size, or described as new species having dimorphic soldiers if huge intraspecific variations were recognized. In this paper, I do not compare our specimens with the Chinese species because I have been unable to access the specimens. Xia and He (1986) erected two subgenera, Oligocrinitermes and Polycrinitermes, based to the number of setae behind the fontanelle and antennal sockets without giving full descriptions of these subgenera. Instead, they offered only short remarks in the Chinese key to justify the division of Coptotermes into these two subgenera. I do not accept this classification because not taxonomic or phylogenetic evidence has been given to support their subgeneric diagnostic characters. Xia and He (1986) also transferred the type species of the genus, $C$. gestroi into the subgenus Oligocrinitermes. However according to ICZN, the type species has to belong to the nominotypical subgenus (Article 44.1). Therefore the subgenus Oligocrinitermes is unavailable as the subgenus of gestroi.

Diagnosis. Monomorphic soldiers. Head oval to subrectangular. Fontanelle prominent, large, with a round opening. Eyes absent. Labrum subtriangular, with a small pointed hyaline tip. Left mandible with crenulations in basal half and a large, knob-shaped basal projection; right mandible without crenulations or teeth. Postmentum club-shaped. 
Pronotum flat.

\section{Key to species of Coptotermes in Thailand}

1. Larger species, HL more than $1.5 \mathrm{~mm}$. Head capsule moderately hairy (Fig. 3A). Mandibles strongly incurved (Fig. 3E) curvignathus Holmgren

-. Smaller species, HL less than $1.5 \mathrm{~mm}$. Head sparsely hairy. Mandibles weakly incurved 2

2. Head moderately narrowed anteriorly, with $\mathrm{bHW} / \mathrm{mHW}$ more than 0.58 . Narrowest part of postmentum located about half way between the widest point and the posterior margin (Fig. 4D) gestroi (Wasmann)

-. Head greatly narrowed anteriorly, with $\mathrm{bHW} / \mathrm{mHW}$ less than 0.55 . Narrowest part of postmentum located about one third of the distance from the posterior margin to the widest point (Fig. 5D)

3. Smaller species, HL less than $1.2 \mathrm{~mm}$ kalshoveni Kemner

-. Larger species, HL more than $1.4 \mathrm{~mm}$ premrasmii Ahmad

\section{Coptotermes curvignathus Holmgren, 1913}

(Fig.3 A-E, Fig. 13 A) 
Cotptermes curvignathus Holmgren, 1913: 77-78, pl.2, fig.11.

Coptotermes robustus Holmgren, 1913: 78. Synonymized by Snyder, 1949, 77.

Material examined. THAILAND: Sakhon Nakhorn: Phu Phan National Park, $550 \mathrm{~m}$ alt., 23.viii.03, Y. Takematsu coll.; Nakhorn Ratchasima: 2 series, Nakhorn Ratchasima, 26.i.98, Y. Takematsu coll.; Sakaerat Environmental Research Station, 29.ix.98, Y. Takematsu coll.; Surat Thani: 3 series, Khao Sok National Park, 300 m alt., 4.xi.02, Y. Takematsu coll.; Songkhla: Prince of Songkla University, Hat Yai, 16.viii.97, Y. Takematsu coll.; Narathiwat: Hara Bara Wildlife Sanctuary, 12.ix.95, Y. Takematsu coll.

Diagnosis. Soldier. Head and pronotum with many long hairs; postmentum with several long hairs. Head considerably narrowed anteriorly, bHW/mHW 0.55-0.61 (0.59); mandibles strongly incurved, LML/HL 0.66-0.74 (0.70). Antennae with 15-16 segments. Narrowest part of postmentum located about one third of the distance from the posterior margin to the widest point.

Measurements (mm) (12 soldiers from 3 series)

Head length without mandibles (HL) $1.52-1.75(1.61)$ 
Maximum width of head (mHW)

Left mandible length (LML)

Pronotum length (PL)

Maximum width of pronotum (PW)

Postmentum length (PosL)

Maximum width of postmentum (PosW)
$1.30-1.56(1.43)$

$1.04-1.18(1.14)$

$0.57-0.65(0.60)$

$0.98-1.14(1.05)$

$1.04-1.11(1.06)$

$0.42-0.46(0.44)$

Distribution. Thailand, Burma, Vietnam, Cambodia, China, Peninsular Malaysia,

Sumatra, Borneo, Java.

Remarks. There is no other species in the Indomalayan region that reaches this large size, although wide variations of head shape and chaetotaxy have been reported (Tho 1992). Strongly incurved mandibles are also diagnostic characters of this species.

[Figure 3 near here]

Coptotermes gestroi (Wasmann, 1896)

(Fig.4 A-E, Fig. 13 B)

Termes gestroi Wasmann, 1896: 628.

Coptotermes gestroi, Holmgren, 1911: 73, pl.5, fig.9. 
Coptotermes javanicus Kemner, 1934: 59. Synonymized by Snyder, 1949, 79.

Coptotermes havilandi Holmgren, 1911: 192. Synonymized by Kirton and Brown, 2003, 47.

Coptotermes travians (Haviland) sensu Roonwal and Chhotani, 1962: Kirton and Brown, 2003, 47.

Coptotermes travians (Haviland) sensu Roonwal and Maiti, 1966: Kirton and Brown, $2003,47$.

Coptotermes travians (Haviland) sensu Roonwal and Chhotani, 1989: Kirton and Brown, 2003, 47.

Coptotermes travians (Haviland) sensu Tho, 1992: Kirton \& Brown, 2003, 47.

Material examined. THAILAND: Chiang Mai: Fang, 14.vi.65, K. Morimoto coll.

[NHML]; Mae Klang Waterfall, Ban Luang, 11.vi.65, K. Morimoto coll. (identified as havilandi by K. Morimoto) [NHML]; Tak: Mae Sod, 17.iv.62, M. Ahmad coll.

[NHML]; Lampang: Jae Sorn National Park, 600 m alt., 27.vi.00, Y. Takematsu coll.;

Sakhon Nakhorn: Phu Phan National Park, 360 m alt., 24.viii.03, Y. Takematsu coll.;

Nakhorn Ratchasima: Nakhorn Ratchasima, 23.i.98, Y. Takematsu coll.; Bangkok:

Bangkok, 24.ii.99, C. Klanckew coll.; Kanchanaburi: Khaoen Srinakarin Dam 
National Park, 28.iii.98, Y. Takematsu coll.; Surat Thani: Koh Saam Sao, Mu Ko Ang Thong National Park, 20.iii.03, Y. Takematsu coll.; Khao Pla Teao Wildlife

Conservation, 3.xi.02, Y. Takematsu coll.; Khao Sok National Park, 300 m alt., 4.xi.02, Y. Takematsu coll.; Phuket: Bang Kanoon, Phuket Is., 13.vi.97, Y. Sornnuwat coll.; Ban Kanoon, Phuket Is., 3.xi.02, Y. Takematsu coll.; Trang: Ka Chong, 6.iii.62, M. Ahmad coll. (identified as havilandi by M. Ahmad) [NHML]; Narathiwat: Hara Bara Wildlife Sanctuary, 22.i.99, Y. Sornnuwat coll.; Phu To Daeng, 31.v.97, Y. Takematsu coll.

Diagnosis. Soldier. Head sparsely hairy; pronotum scantily hairy or bald on the dorsal surface; postmentum with several long hairs. Head elongately oval, narrowed anteriorly, bHW/mHW 0.58-0.65 (0.61); mandibles moderately incurved, LML/HL 0.58-0.64 (0.61). Antennae with 14-15 segments. Narrowest part of postmentum located about half way between the widest point and the posterior margin

Measurements (mm) (25 soldiers from 10 series)

Head length without mandibles (HL) $1.28-1.45(1.37)$

Maximum width of head (mHW)

Left mandible length (LML) $0.82-0.86(0.85)$ 
Pronotum length (PL)

Maximum width of pronotum (PW)

Postmentum length (PosL)

Maximum width of postmentum (PosW)
$0.40-0.44(0.42)$

$0.78-0.85(0.82)$

$0.90-1.00(0.96)$

$0.37-0.42(0.40)$

Distribution. Thailand, Burma, China, Peninsular Malaysia, Sumatra, Borneo, Java, India (excludes areas where it has been introduced by humans).

Remarks. This species is widely distributed throughout Thailand (Fig. 13 B) and is a serious pest of construction timber.

This species has a wide variation of size and was often confused with havilandi, which was also a pest species Southeast Asia. However, Kirton and Brown (2003) reviewed the taxonomy of pest species in Southeast Asia and synonymized havilandi as a junior synonym of gestroi. $C$. gestroi can easily be distinguished from other species in Thailand by having oval head, less narrowed anteriorly.

[Figure 4 near here]

\section{Coptotermes kalshoveni Kemner, 1934}

(Fig.5 A-E, Fig. 13 C) 
Coptotermes kalshoveni Kemner, 1934: 61.

Material examined. THAILAND: Trang: Ka Chong, 3.iii.62, M. Ahmad coll.

[NHML]; Narathiwat: 2 series, Hara Bara Wildlife Sanctuary, 300 m alt., 29.v.97, Y.

Takematsu coll.; Phu To Daeng, 31.v.97, Y. Takematsu coll.

Diagnosis. Soldier. Head and pronotum sparsely hairy; postmentum with several long hairs. Head subcircular, considerably narrowed anteriorly, bHW/mHW 0.50-0.55

(0.52); mandibles weakly incurved, LML/HL 0.57-0.63 (0.59). Antennae with 13-14 segments. Narrowest part of postmentum located about one third of the distance from the posterior margin to the widest point.

Measurements (mm) (11 soldiers from 3 series)

Head length without mandibles (HL)

$1.04-1.20(1.10)$

Maximum width of head (mHW)

$0.94-1.01(0.97)$

Left mandible length (LML)

$0.61-0.74(0.65)$

Pronotum length (PL)

$0.35-0.40(0.37)$

Maximum width of pronotum (PW)

$0.60-0.73(0.65)$

Postmentum length (PosL)

$0.61-0.70(0.65)$ 
Distribution. Thailand (South), Peninsular Malaysia, Sumatra, Borneo, Java.

Remarks. This species has only been recorded south of the Kra Isthmus (Fig. 13 C).

This small species can be distinguished from the smaller individuals of gestroi by having a more rounded head that is strongly narrowed anteriorly, and the postmentum narrowest near the posterior end.

[Figure 5 near here]

Coptotermes premrasmii Ahmad, 1965

Coptotermes premrasmii Ahmad, 1965: 17-19, fig.11.

(Fig. 13 D)

Distribution. Thailand (South).

Remarks. This species was described by Ahmad (1965) from only 2 soldiers, and has not been recorded since. We did not collect this species. Judging from the original description, this species has a similar shape of head capsule to kalshoveni but the size is much larger than kalshoveni and the chaetotaxy on the head is more sparse. 


\section{Parrhinotermes Holmgren, 1910}

Type species: Parrhinotermes aequalis (Haviland, 1898)

This genus is distributed in the Indomalayan and Australian regions, and 9 species have been recorded from the Indomalayan region. These species were mainly separated by the shape of the right mandible and the head size. This genus is newly recorded from Thailand. In the course of our survey we have collected 4 series of Parrhinotermes all from South of the Kra Isthmus.

Diagnosis. Monomorphic soldiers. Head subrectangular, flat in lateral view. Fontanelle small and circular, located directly between the antennal sockets. Eyes absent. Labrum tongue-shaped. Inner margin of bases of mandibles finely serrated; left mandible with two marginal teeth; right mandible with one marginal tooth. Postmentum club-shaped. Pronotum flat, much narrower than head width.

\section{Key to species of Parrhinotermes in Thailand}

1. Marginal tooth of right mandible located in middle, posterior cutting edge strongly 
concave (Fig. 7F arrow). Third antennal segment one and a half times as long as the forth (Fig. 7E) microdentiformisoides Thapa

-. Marginal tooth of right mandible located in anterior third, posterior cutting edge not distinctly concave (Fig. 6F). Third antennal segment as long as the forth (Fig. $6 \mathrm{E})$ buttelreepeni Holmgren

Parrhinotermes buttelreepeni Holmgren, 1913

(Fig. 6 A-F, Fig. 14 A)

Parrhinotermes buttelreepeni Holmgren, 1913: 79.

Material examined. THAILAND: Narathiwat: Narathiwat, 29.xi.88, T. Abe coll.

Redescription. Soldier. Head capsule pale yellow; antennae pale yellow; labrum pale brownish yellow; mandibles pale brown, paler basally. Thoracic nota pale yellow; legs and abdomen pale yellow. Head sparsely hairy; labrum with several hairs on the anterior half and many minute hairs along the anterior margin; pronotum with a few hairs on the surface and many hairs along the margin. Postmentum with scattered hairs. Head capsule subrectangular, widest at just below middle, longer than wide, mHW/HL 0.85 . Fontanelle small, circular. Eyes absent. Antennae with 13 segments; 3rd segment as 
long as 2 nd and 4 th. Labrum longer than wide. Mandibles incurved in middle, inner margin of bases finely serrated, slightly longer than half the length of the head, LML/HL 0.58; left mandible bent in middle, with two anterior directed, pointed marginal teeth, 1st marginal tooth located at anterior one third of mandible, moderately larger than 2nd; right mandible with a marginal tooth located at anterior one forth of the mandible, pointed, posterior cutting edge not distinctly concave. Postmentum almost two and half times as long as the maximum width; widest almost at the anterior third; narrowest at the posterior third. Pronotum flat, with anterior margin slightly convex, notched in middle. Mesonotum slightly narrower than pronotum. Metanotum almost as wide as pronotum.

Measurements (mm) (1 soldier from 1 series)

Head length without mandibles (HL) $\quad 0.90$

Maximum width of head (mHW) $\quad 0.77$

Left mandible length (LML) $\quad 0.52$

Pronotum length (PL) $\quad 0.26$

Maximum width of pronotum (PW) $\quad 0.47$

Postmentum length (PosL) $\quad 0.66$ 
Distribution. Thailand (South), Peninsular Malaysia, Borneo, Sumatra. New record for Thailand.

Remarks. Only one colony was collected, from Narathiwat on the border of Malaysia. This species is similar to pygmaeus John, 1925 as the marginal tooth of the right mandible is located at the anterior third. However, it is easily distinguished by its smaller size and remarkably different shape of head capsule. The head capsule of pygmaeus is flat in profile and the lateral margins of the head are strongly convex unlike buttelreepeni.

[Figure 6 near here]

Parrhinotermes microdentiformisoides Thapa, 1981

(Fig. 7 A-F, Fig. 14 B)

Parrhinotermes microdentiformisoides Thapa, 1981: 106-108, pl.35.

Material examined. THAILAND: Surat Thani: 3 series, Khao Sok National Park, 400 m alt., 5.xi.02, Y. Takematsu coll. 
Redescription. Soldier. Head capsule pale yellow; antennae pale yellow; labrum pale brownish yellow; mandibles brown, paler basally. Thoracic nota pale yellow; legs and abdomen pale yellow. Head sparsely hairy; labrum with several hairs on the anterior half and many minute hairs along the anterior margin; pronotum with a few hairs on the surface and many hairs along margin. Postmentum with scattered hairs. Head capsule subrectangular, widest at posterior third, longer than wide, mHW/HL 0.86-0.91 (0.88). Fontanelle small, circular. Eyes absent. Antennae with 13 segments; 3rd segment much longer than 2nd and 4th. Labrum broadly rounded. Mandibles broad basally, strongly incurved, inner margin of bases finely serrated, mandibles half the length of the head, LML/HL 0.49-0.52 (0.50); left mandible strongly bent in middle, with two broadly triangular marginal teeth, 1st marginal tooth located at middle, much bigger than 2nd; right mandible with a marginal tooth in the middle, not pointed, posterior cutting edge strongly concave. Postmentum almost three times as long as the maximum width; widest almost at the anterior third; narrowest at the posterior third. Pronotum flat, with anterior margin slightly convex, notched in middle. Mesonotum slightly narrower than pronotum. Metanotum almost as wide as pronotum.

Measurements (mm) (10 soldiers from 3 series) 
Head length without mandibles (HL)

$1.08-1.20(1.15)$

Maximum width of head (mHW)

$0.98-1.07(1.01)$

Left mandible length (LML)

$0.58-0.60(0.58)$

Pronotum length (PL)

$0.30-0.32(0.31)$

Maximum width of pronotum (PW)

$0.58-0.61(0.59)$

Postmentum length (PosL)

$0.85-0.90(0.87)$

Maximum width of postmentum (PosW)

$0.29-0.32(0.31)$

Distribution. Thailand (South), Borneo. New record for Thailand.

Remarks. This species was collected only from Khao Sok, south of the Kra Isthmus.

This species and microdentiformis Thapa, 1981 are similar and easily distinguished

from the other species in the genus by having a marginal tooth on the right mandible

with its posterior cutting edge strongly concave. But microdentiformisoides is distinctly

smaller than microdentiformis.

[Figure 7 near here]

Prorhinotermes Silvestri, 1909

Type species: Prorhinotermes inopinatus Silvestri, 1909 
There are about 10 species of the genus in the Indomalayan region. One species, $P$.

tibiaoensiformis, was described from North Thailand by Ahmad (1965). However,

Gathorne-Hardy (2004) made this species a junior synonym of Prorhinotermes flavus.

Diagnosis. Monomorphic soldiers. Head oval. Fontanelle small and circular. Eyes present but pale. Labrum tongue-shaped. Mandible saber-shaped, without teeth.

Postmentum club-shaped. Pronotum flat.

Prorhinotermes flavus (Bugnion and Popoff, 1910)

(Fig. 8 A-D, Fig. 14 C)

Coptotermes flavus Bugnion and Popoff, 1910: 117-120, pl.2, figs.14-20.

Arrhinotermes flavus, Holmgren, 1911, 551.

Prorhinotermes flavus, Snyder, 1949: 86.

Arrhinotermes japonicus Holmgren, 1912: 122.

Prorhinotermes japonicus, Snyder, 1949: 86. Synonymized by Gathorne-Hardy, 2004, 94.

Arrhinotermes krakataui Holmgren, 1913:69.

Prorhinotermes krakataui, Snyder, 1949, 87. Synonymized by Gathorne-Hardy, 2004, 
94.

Termitogetonella tibiaoensis Oshima, 1920:496.

Prorhinotermes tibiaoensis, Snyder, 1949, 88. Synonymized by Gathorne-Hardy, 2004, 95.

Prorhinotermes gracilis Light, 1921: 54. Synonymized by Gathorne-Hardy, 2004, 95.

Prorhinotermes tibiaoensiformis Ahmad, 1965: 23-24, fig.17. Synonymized by

Gathorne-Hardy, 2004, 95.

Prorhinotermes ravani Roonwal and Maiti, 1966: 84-90, figs.3-4. Synonymized by

Gathorne-Hardy, 2004, 95.

Prorhinotermes panaitanensis Thakur and Thakur, 1992: 251-257, figs.14-15.

Synonymized by Gathorne-Hardy, 2004, 95.

Material examined. THAILAND: Petchabun: Wang Nok An, 11.iv.62, M. Ahmad coll. (type colony of tibiaoensiformis) [NHML]

Diagnosis. Soldier. Head and pronotum yellow, sparsely hairy. Postmentum with several hairs only on the anterolateral margins. Head oval, widest at the posterior forth, narrowed anteriorly. Fontanelle small, circular, with a groove running in frons. Eyes whitish but distinct, broadly oval. Mandible long, saber-shaped, weakly incurved. 
Antannae with 15 segments. Postmentum much longer than wide.

Measurements ( $\mathrm{mm})$ (2 soldiers from 1 series)

Head length without mandibles (HL)

$1.70 \quad 1.72$

Maximum width of head (mHW)

$1.40 \quad 1.50$

Left mandible length (LML)

$1.20 \quad 1.23$

Pronotum length (PL)

$0.60 \quad 0.60$

Maximum width of pronotum (PW)

$1.10 \quad 1.19$

Postmentum length (PosL)

$1.10 \quad 1.10$

Maximum width of postmentum (PosW)

$0.48 \quad 0.50$

Distribution. Thailand (North), India, Sri Lanka, Bangladesh, Taiwan, Philippines,

Peninsular Malaysia, Borneo, Java, Krakatau.

Remarks. Ahmad (1965) described this small series from northern Thailand as $P$.

tibiaoensiformis. We did not collect this species during our survey. In this paper, I

investigated the specimens from the type colony deposited in NHML. According to the original description, P. tibiaoensiformis was very similar to tibiaoensis but distinguished from tibiaoensis by having less strongly curved mandibles and smaller 
pronotum. However these characters were variable and both tibiaoensis and tibiaoensiformis were put into flavus as junior synonyms of the species by Gathorne-Hardy (2004). Gathorne-Hardy (2004) also considered five other species, japonicus, krakataui, gracilis, ravani and panaitanensis, as junior synonyms of flavus because these variations fell into the intraspecific variation of flavus. Ahmad collected it from Wang Nok An which is located 250 miles from the coast. This species is usually associated with coastal forests and mangroves.

[Figure 8 near here]

\section{Reticulitermes Holmgren, 1913}

Type species: Reticulitermes flavipes (Kollar, 1837)

Genus Reticulitermes is widely distributed in the northern temperate zone. But several species are distributed in the cooler mountain areas of northern India and the southern China. The southernmost record of this genus was Dalat, Vietnam (Emerson 1971). This is a first record of the genus from Thailand.

All the species of this genus have very similar morphology and therefore the diagnostic characters are very poor. The numerical characters such as head index (ration 
of width to length) and size have mainly been used as the diagnostic characters, but these characters tend to be continuous between species. There are a few distinct morphological characters, such as chaetotaxcy and postmentum shape. This situation has led to many species being described in China without adequate examination of the full extent of the intra- and inter-specific within Reticulitermes. About ten species in the genus have been described from the Indomalaysian region. However, another 74 species were described from China, including 56 species described the 1960s. (Huang et al. 1989). In spite of the continuity of the diagnostic characters, almost all the Chinese species were described from a limited number of specimens and separated by only small differences of size and faint differences of morphology. Revision of the genus in Asia is required. Tsai et al. (1977) divided Reticulitermes into two subgenera, Frontotermes and Planifrontotermes based on the size of the frontal projection. However I do not accept this classification because the subgenera were erected without sufficient descriptions and evidence to show that these were diagnostic characters.

Diagnosis. Head capsule rectangular, much longer than wide, sides almost parallel; frontal area generally raised forming frontal protuberances. Fontanelle minute. Eyes absent. Labrum subtriangular, tongue-shaped. Mandibles weakly incurved; left mandible with 3 small crenulations and a basal projection; right mandible without tooth. 
Postmentum club-shaped. Pronotum flat, narrower than the head width.

\section{Reticulitermes assamensis Gardner, 1944}

(Fig. 9 A-E, Fig. 13 E)

Reticulitermes assamensis Gardner, 1944, 105-106.

Material examined. THAILAND: Nan: 7 series, Doi Phu Kha National Park, 1400 m

alt, 7.xii.03, Y. Takematsu coll.; Leoi: Phu Luang National Park, 1050 m alt, 13.xii.96,

Y. Takematsu coll.; Nakhon Ratchasima: 2 series, Khao Yai National Park, $700 \mathrm{~m}$ alt., 1.xii.98, Y. Takematsu coll.; Khao Yai National Park, $700 \mathrm{~m}$ alt., 4.iii.98, Y. Takematsu coll.; Khao Yai National Park, 500 m alt., 4.iii.98, Y. Takematsu coll.; 4 series, Khao Yai National Park, 1200 m alt., 4.iii.98, Y. Takematsu coll.

Redescription. Soldier. Head capsule pale yellow; antennae pale yellow; labrum yellow; mandibles dark brown, paler basally; thorax and abdomen yellowish white. Head fairly hairy; pronotum fairly hairy with 20-40 hairs on the surface. Postmentum with several hairs in the anterior half. Head capsule rectangular, parallel-sided or slightly concave at posterolateral ends of antennal sockets, much longer than wide, maximum width slightly more than half of the length, mHW/HL $0.53-0.60(0.56)$; 
frontal protuberances prominently swollen. Fontanelle minute, located at a little behind middle of frontal protuberances. Antennae with 14-17 segments. The number of segments increases as the body size increases. Labrum triangularly tongue shaped, with a pair of long bristles at tip. Mandibles weakly incurved; length slightly more than half of head length. Left mandible with 3 small crenulations and a basal projection; right mandible with straight inner margin. Postmentum club-shaped with a long narrow stalk, narrowest part almost ten times as long as length, minimum width of postmentum $0.12-0.18(0.15)$. Pronotum flat, narrower than head, with anterior margin slightly concave, notched in middle.

Measurements (mm)

Thai-specimens $\quad$ R. assamensis* R. tirapi* $^{*}$ ( 25 soldiers from 12 series)

\begin{tabular}{|c|c|c|c|}
\hline Head length without mandibles (HL) & $1.64-2.03(1.83)$ & $1.75-2.32$ & $1.87-2.03$ \\
\hline Maximum width of head (mHW) & $0.95-1.15(1.03)$ & $1.08-1.30$ & $1.05-1.10$ \\
\hline Left mandible length (LML) & $0.91-1.06(1.00)$ & $0.95-1.15$ & $1.00-1.05$ \\
\hline Pronotum length (PL) & $0.43-0.60(0.50)$ & $0.42-0.62$ & $0.45-0.55$ \\
\hline Maximum width of pronotum (PW) & $0.71-0.96(0.81)$ & $0.77-0.97$ & $0.80-0.87$ \\
\hline
\end{tabular}




$\begin{array}{llll}\text { Postmentum length (PosL) } & 1.22-1.56(1.37) & 1.00-1.52 & 1.30-1.43 \\ \text { Maximum width of postmentum } & 0.39-0.50(0.44) & 0.42-0.52 & 0.45-0.50 \\ \text { Minimum width of postmentum } & 0.12-0.18(0.15) & 0.12-0.17 & 0.12-0.15 \\ \text { Number of antennal segments } & 15-16 & 15-16 & 14-17 \\ \text { mHW/HL } & 0.53-0.60(0.56) & 0.56-0.62 & 0.54-0.58\end{array}$

* The measurements of assamensis and tirapi are from Chhotani and Das (1983).

Distribution. Thailand (Northeast, North), India, China. New record for Thailand.

Remarks. The samples collected from Thailand are morphologically the same as assamensis and tirapi Chhotani and Das, 1983 from India and southern China. They are distinguished from the other Reticulitermes species by having a longer and narrower head, many setae on pronotum, almost straight mandibles and distinctly prominent frontal projection. Chhotani and Das (1983) distinguished tirapi from assamensis by the narrower head and pronotum, however the measurements of these characters overlap and these two species can not be distinguished by the descriptions. The specimens in Thailand increased in size towards the north and were relatively smaller than the sizes given in Chhotani and Das (1983), although they could not be separated clearly. As the results, I concluded that the species in Thailand is $R$. assamensis and showed a 
geographical cline from south to north. To clarify the relationship of assamensis and tirapi, further investigation is needed.

In Thailand it is distributed only at mid to high elevations $(500-1400 \mathrm{~m})$ in the central mountain ranges, Luan Phrabang mountain range and Phetchabun mountain range (Fig. $13 \mathrm{E}$ ). It is possibly a relic distribution from the last glacial maximum. [Figure 9 near here]

\section{Schedorhinotermes Silvestri, 1909}

Type species: Schedorhinotermes intermedius (Brauer, 1865)

The genus has dimorphic soldiers and the major soldier and minor soldier are very different morphologically. The diagnostic characters used in keys are mainly head shape, size and the number of antennal segments, but sometimes these characters are variable even within a colony. The morphological differences of minor soldiers are very small and it is impossible to identify the species by using the conventional diagnostic characters of minor soldiers. The proportion of minor soldiers is much larger than majors, and it is not unusual to collect only minor soldiers. Therefore it is important to be able to identify the species from the minor soldiers. 
There are more than 20 species in the Indomalayan region. Gathorne-Hardy (2004) observed many specimens of Schedorhinotermes from the region and synonomized several species. Three species are recorded from Thailand. One was described by Ahmad (1965) but the diagnostic characters of minor soldiers were too vague to distinguish them from the other two species.

In this paper, I present clear differences among species of both major and minor soldiers.

Diagnosis. Dimorphic soldiers. Major soldier. Head subrectangular, slightly to greatly narrowed anteriorly. Fontanelle open and circular, with a groove running to the tip of the labrum. Eyes absent. Labrum weakly bi-lobed at tip. Left mandible with two marginal teeth; right mandible with one marginal tooth. Postmentum club-shaped. Pronotum flat. Minor soldier. Much smaller than the major soldier. Head subrectangular. Fontanelle open and circular, with a groove running to the tip of the labrum. Labrum long, extended beyond mandibles; tip bi-lobed. Left mandible with two marginal teeth; right mandible with one marginal tooth. Postmentum club-shaped. Pronotum flat.

Key to species of Schedorhinotermes in Thailand. 


\section{Major soldier}

1. Larger species, head length without mandible more than $2.0 \mathrm{~mm}$, maximum width of head more than $2.2 \mathrm{~mm}$ malaccensis (Holmgren)

-. Smaller species, head length without mandible less than $1.9 \mathrm{~mm}$, maximum width of head less than $1.7 \mathrm{~mm}$

2. Head capsule and pronotum with several hairs (Figs. 11A, C). Inner edge of apical tooth of left mandible convex. The basal part of right mandible with a broad step (Fig. $11 \mathrm{E}$ arrow) medioobscurus (Holmgren)

-. Head capsule and pronotum without hair (Figs. 12A, C). Inner edge of apical tooth of left mandible not convex. The basal part of right mandible without a broad step (Fig. 12E) rectangularis Ahmad

\section{Minor soldier}

1. Larger species, head length without mandible more than $0.95 \mathrm{~mm}$, maximum width of head more than $0.95 \mathrm{~mm}$. Head almost parallel sided or slightly convex (Fig. $10 \mathrm{~F})$ malaccensis (Holmgren)

-. Smaller species, head length without mandible less than $0.90 \mathrm{~mm}$, maximum width of head less than $0.80 \mathrm{~mm}$. Head widest at posterolateral end of antennal sockets 2 
2. Apical teeth short, weakly incurved, DAM1/DM1M2 less than 1.3 (Fig. 11J). Postmentum without a projection, smoothly arched in the lateral view (Fig. $11 \mathrm{G})$ medioobscurus (Holmgren)

-. Apical teeth long, strongly incurved, DAM1/DM1M2 more than 1.3 (Fig. 12J). Postmentum with a faint projection at anterior one third in the lateral view (Fig. 12G arrow) rectangularis Ahmad

Schedorhinotermes malaccensis (Holmgren, 1913)

(Fig. 10 A-J, Fig. 14 D)

Rhinotermes (Schedorhinotermes) malaccensis Holmgren, 1913: 86, pl.2, figs.12, 19.

Schedorhinotermes malaccensis, Snyder, 1949: 93.

Schedorhinotermes sarawakensis Holmgren, 1913: 87, pl.2, figs.13,18. Synonymized by Gathorne-Hardy, 2004, 90-91.

Material examined. THAILAND: Chiang Mai: Doi Suthep-Pui National Park, 10.vi.65, K. Morimoto coll. (identified as sarawakensis by K. Morimoto) [NHML]; 3 series, Doi Suthep-Pui National Park, 1500 m alt., 8.ix.97, Y. Takematsu coll.; Lampang: Jae Sorn National Park, 600 m alt., 27.vi.00, Y. Takematsu coll.; Tak: Mae 
Sod, 19.iv.62, M. Ahmad coll. (identified as sarawakensis by M. Ahmad) [NHML];

Surat Thani: Khao Sok National Park, 400 m alt., 5.xi.02, Y. Takematsu coll.; Phuket:

Bang Kanoon, Phuket Is., 3,xi.02, Y. Takematsu coll.; Narathiwat: 3 series, Hara Bara Wildlife Sanctuary, 29.v.97, Y. Takematsu coll.; Narathiwat, 20.xii.97, Y. Sornnuwat coll.

Diagnosis. Major soldier. Large species. Head subtriangular, strongly narrowed anteriorly, sparsely hairy on head capsule. Eyes present, but small and whitish. Inner edge of apical tooth of left mandible convex; the basal part of right mandible without a step. Antennae with 16-18 segments. Minor soldier. Large species. Head almost parallel-sided or slightly convex, with several hairs on head capsule. Eyes present, broadly oval, whitish, slightly bulging. 1st marginal teeth of left mandible located almost at the middle between apical teeth and 2nd marginal teeth, DAM1/DM1M2 1.00-1.08 (1.04). Antennae with 15-16 segments. Postmentum weakly arched and smooth in lateral view.

Measurements (mm)

Major soldier (13 soldiers from 4 series)

Head length without mandibles (HL) 2.08-2.40 (2.27) 
Minor soldier (20 soldiers from 4 series)

Head length without mandibles (HL)

Maximum width of head (mHW)

$0.95-1.21(1.08)$

Left mandible length (LML)

$0.79-0.94(0.85)$

Pronotum length (PL)

$0.47-0.55(0.52)$

Maximum width of pronotum (PW)

$0.70-0.86(0.78)$

Postmentum length (PosL)

$0.70-0.90(0.81)$

Maximum width of postmentum (PosW)

$0.35-0.38(0.36)$

Distribution. Thailand, Cambodia, Vietnam, India, Burma, Peninsular Malaysia, Borneo, Sumatra, Java. 
Remarks. This species is much larger than the other two Schedorhinotermes species recorded from Thailand. It had been recorded as S. sarawakensis. Both species, malaccensis and sarawakensis were described by Holmgren (1913). In the original descriptions, malaccensis was distinguished from sarawakensis by its larger size and having 17 antennal segments and broader pronotum in the major soldier, and 17 antennal segments and shorter labrum in the minor solider. These characters are highly variable and Tho (1992) speculated that these two species were the same.

Gathorne-Hardy (2004) observed many specimens of Schedorhinotermes and concluded that they were the same. Judging from my observations of many specimens and type specimens and their descriptions, I have also concluded that both species are the same. There is considerable size variation within species, with the result that smaller specimens and larger specimens may appear to be different species when in fact they are the same. Holmgren described these species in the same paper (Holmgren 1913), but $S$. malaccensis is a valid name because it was described in the earlier page (p86) than sarawakensis (p.87).

[Figure 10 near here] 
(Fig. 11 A-J, Fig. 14 E)

Rhinotermes (Schedorhinotermes) brevialatus f. medioobscurus Holmgren, 1914: 241.

Schedorhinotermes medioobscurus, Snyder, 1949: 94.

Rhinotermes (Schedorhinotermes) tarakanensis Oshima, 1914: 564, pl.10, fig.2.

Schedorhinotermes tarakanensis, Roonwal \& Maiti, 1966, 91. Synonymized by

Gathorne-Hardy, 2004, 92.

Schedorhinotermes javanicus Kemner, 1934: 51-54, fig.7. Synonymized by

Gathorne-Hardy, 2004, 92-93.

Material examined. THAILAND: Chiang Mai: 2 series, Doi Inthanon National Park, 1100 m alt., 5ix.97, Y. Takematsu coll.; Petchabun: Tung Salang Luang Nationak Park, 8.iv.62, M. Ahmad coll. [NHML]; Sakhon Nakhorn: Phu Phan National Park, 550 m alt., 23.viii.03, Y. Takematsu coll.; Nakhorn Ratchasima: Nakhorn Ratchasima, 1.xi.99, Y. Takematsu coll.; 3 series, Sakaerat Environmental Research Station, 20.viii.97, Y. Takematsu coll.; Sakaerat Environmental Research Station, 21.i.98, I. Tayasu coll.; 5 series, Khao Yai National Park, 700 m alt., 1.xii.98, Y. Takematsu coll.; Trat: Koh Kood, 14.iii.97, Y. Sornnuwat coll.; Prachuap Khiri Khan: Namtok Huai Yang National Park, 300 m alt., 7.xi.02, Y. Takematsu coll.; Surat Thani: 4 series, 
Khao Sok National Park, 400 m alt., 4.xi.02, Y. Takematsu coll.; Phuket: 2 series, Bang Kanoon, Phuket Is., 11.xi.98, Y. Sornnuwat coll.; Bang Kanoon, Phuket Is., 3.xi.02, Y.

Takematsu coll.; Narathiwat: 3 series, Hara Bara Wildlife Sanctuary, 300 m alt., 29.v.97, Y. Takematsu coll.; Phu To Deang, 31.v.97, Y. Takematsu coll.; Narathiwat, 25.ix.95, Y. Sornnuwat coll.

Diagnosis. Major soldier. Small species. Head subtriangular to subrectangular, widest at posterior third and moderately narrowed anteriorly, sparsely hairy on head capsule. Eyes present, but small and whitish. Inner edge of apical tooth of left mandible convex; the basal part of the right mandible with a distinct step. Antennae with 15-17 segments. Minor soldier. Small species. Head widest at posterolateral end of antennal sockets and slightly narrowed posteriorly, with several hairs on head capsule. Eyes present, oval, but whitish and faint. Apical tooth short and weakly incurved, DAM1/DM1M2 1.13-1.27 (1.21). Antennae with 15-16 segments. Postmentum without a projection, smoothly arched in lateral view.

Measurements (mm)

Major soldier (40 soldiers from 20 series)

Head length without mandibles (HL) $1.28-1.82(1.56)$ 
Minor soldier (15 soldiers from 5 series)

Head length without mandibles (HL)

$0.82-0.87(0.83)$

Maximum width of head (mHW)

$0.69-0.78(0.74)$

Left mandible length (LML)

$0.56-0.65(0.61)$

Pronotum length (PL)

$0.37-0.42(0.40)$

Maximum width of pronotum (PW)

$0.54-0.67(0.59)$

Postmentum length (PosL)

$0.54-0.63(0.60)$

Maximum width of postmentum (PosW)

$0.29-0.33(0.31)$

Distribution. Thailand, Cambodia, Vietnam, India, Peninsular Malaysia, Sumatra, Borneo, Java. 
Remarks. This species is widely distributed in Southeast Asia including throughout Thailand. The Schedorhinotermes species in the Indomalayan region have been separated by size, head shape and the number of antennal segments. However, these characters are variable and overlap. Gathorne-Hardy (2004) observed many specimens and concluded that javanicus and tarakanensis were junior synonyms of medioobscurus.

This species is similar to rectangularis in size, but easily distinguished by the sparsely hairy head of the major soldier, and shorter apical teeth on the minor soldier.

[Figure 11 near here]

\section{Schedorhinotermes rectangularis Ahmad, 1965}

(Fig. 12 A-J, Fig. 14 F)

Schedorhinotermes rectangularis Ahmad, 1965: 27-29, figs.21-22.

Material examined. THAILAND: Nakhorn Ratchasima: 3 series, Khao Yai National

Park, 700 m alt., 4.iii.98, Y. Takematsu coll.; Chanthaburi: Chanthaburi, 26.iii.65, M.

Ahmad coll. [BMNH].

Diagnosis. Major soldier. Small species. Head rectangular, almost parallel-sided, 
without hairs on head capsule and pronotum. Eyes present, but small and whitish. Inner edge of apical tooth of left mandible not convex; the basal part of the right mandible without a distinct step. Antennae with 16-17 segments. Minor soldier. Small species. Head widest at posterolateral end of antennal sockets and slightly narrowed posteriorly, with four hairs on head capsule. Eyes present, oval, but whitish and faint. Apical tooth long and strongly incurved, DAM1/DM1M2 1.33-1.47 (1.40). Antennae with 15-16 segments. Postmentum arched, with a faint projection at anterior one third in lateral view.

Measurements (mm)

Major soldier (6 soldiers from 3 series)

Head length without mandibles (HL)

$1.36-1.54(1.49)$

Maximum width of head (mHW)

$1.16-1.31(1.27)$

Left mandible length (LML)

$0.88-0.94(0.91)$

Pronotum length (PL)

$0.40-0.45(0.43)$

Maximum width of pronotum (PW)

$0.71-0.84(0.78)$

Postmentum length (PosL)

$0.94-1.14(1.07)$

Maximum width of postmentum (PosW)

$0.44-0.46(0.45)$ 
Minor soldier (12 soldiers from 3 series)

Head length without mandibles (HL)

$0.72-0.82(0.79)$

Maximum width of head (mHW)

$0.64-0.74(0.70)$

Left mandible length (LML)

$0.58-0.64(0.61)$

Pronotum length (PL)

$0.31-0.38(0.34)$

Maximum width of pronotum (PW)

$0.46-0.56(0.52)$

Postmentum length (PosL)

$0.48-0.55(0.52)$

Maximum width of postmentum (PosW)

$0.27-0.31(0.29)$

Distribution. Thailand (Northeast, East).

Remarks. This species is similar to medioobscurus in size. Ahmad distinguished this species from medioobscurus by their head shapes and the number of antennal segments.

In the major soldier, rectangularis has a relatively rectangular head compared with medioobscurus, but the ranges of head length/width index of both species are almost overlapping. These two species could not be separated clearly by this character. However this species is easily distinguished from medioobscurus by the other characters as follows; no hair on head capsule and pronotum; inner edge of apical tooth of left 
mandible not convex; apical teeth short; posterior part of marginal teeth of right

mandible not swollen. In the minor soldier, it is difficult to separate these species. The number of antennal segments which Ahmad used to distinguish both species is variable within a colony. Ahmad also distinguished rectangularis from medioobscurus by lateral side of head capsule not being concave. But this character state is so faint that it is difficult to recognize. From my careful observations, rectangularis has only two pairs of long bristles on the head capsule (medioobscurus has more than three pairs), although there are some exceptional individuals. It also distinguished by having longer apical teeth. The postmentum of rectangularis has a small projection on the anterior third in lateral view, but medioobscurus does not.

[Figure 12 near here]

\section{Distributions of Rhinotermitidae in Thailand}

Species distribution maps are shown in Figs. 13-14.

There has been general agreement that the biogeographic transition between the Sundaic fauna (Peninsular Malaysia, Sumatra, Borneo, Java and associated islands) and the continental Indomalayan fauna occurs on the Thai/Malaysian peninsula. Hypotheses as the exact location of the biological boundary varies from the northern end of the 
peninsular (around $14 \mathrm{~N}^{\circ}$ ) to the Kra Isthmus (around $10 \mathrm{~N}^{\circ}$ ), which is the narrowest land bridge connecting Peninsula Malaysia to the continental part of Asia (Wallace 1869; Walls 1976; Hughes et al. 2003; Woodruff 2003). The Kra Isthmus is located between two of our sampling sites: Namtok Huai Yang National Park (Prachuap Khiri Khan Prov., Fig.1-18) and Khao Pla Teao Wildlife Conservation (Surat Thani Prov., Fig.1-20).

Taking account of the biogeographical boundary, termites in Thailand show three distinct distribution patterns: (1) species that occur in Thailand's continental land area, (2) species that occur only in Thailand's peninsula, and (3) species that occur throughout the country, in both the peninsula and the continental area. The 11 species that have been recorded in this survey can be grouped in the following way. Three species have a continental distribution; Reticulitermes assamensis, Schedorhinotermes rectangularis and Prorhinotermes flavus. Prorhinotermes flavus is usually found in coastal forests and mangroves, and has a wide distributional range from India to Indonesia. Although there is only one record in North Thailand, it is very possible that this species also occurs along parts of Thailand's coastline. The record of Reticulitermes in Central Thailand is one of the southernmost records in the Indomalayan region for this genus. This genus is restricted to the Continental part of Thailand. Four species are 
restricted to the peninsula; Coptotermes premrasmii, C. kalshoveni, Parrhinotermes

micordentiformisoides and $P$. buttelreepeni. The northernmost distribution of this group was that of P. micordentiformisoides (Fig. 14 B), which was far south of the Kra

Isthmus. Four species are found throughout Thailand; Coptotermes curvignathus, $C$.

gestroi, Schedorhinotermes malaccensis and S. medioobscurus.

[Figure 13 near here]

[Figure 14 near here]

\section{Acknowledgements}

I would like to give my gratitude to Dr. P. Eggleton and Dr. D.T. Jones, of the Natural History Museum, London, for valuable advice and critical reading of this manuscript. I am grateful to the Department of Entomology, Natural History Museum, London for providing me with access to specimens and literature. I thank the National Research Council of Thailand (NRCT) for the permission of this research. The study was carried out within the framework of an integrated study on biodiversity conservation under global change and bio-inventory management system supported by a Grant-in-Aid for Creative Basic Research from the Japanese Ministry of Education, Science and Culture and a grant from the International Cooperative Research Project (Bio-Recycle Project) from Japan Science and Technology Corporation.

\section{References}

Ahmad M. 1965. Termites (Isoptera) of Thailand. Bull. Am. Mus. Nat. Hist. 131(1): 
$1-114$.

Brauer F. 1865. Fünfter Bericht über die auf der Weltfahrt der Kais. Fregatte Novara gesammelten Neuropteren. 2. Termiten. Verhandl. Zool.-Bot. Ges. Wien. 15: 977.

Bugnion E, Popoff N. 1910. Le termite a latex de Ceylon (Coptotermes travians Haviland). Avec un appendice comprenant la description des Coptotermes Gestroi Wasm. et flavus nov. sp. Mém. Soc. Zool. France. 23(8): 107-123.

Chhotani OB, Das BC. 1983. A review of the Indian species of the genus Reticulitermes Holmgren (Isoptera: Rhinotermitidae). Rec. Zool. Surv. India. 80: 315-329. Emerson AE. 1971. Tertiary fossil species of the Rhinotermitidae (Isoptera), phylogeny of genera, and reciprocal phylogeny of associated Flagellata (Protozoa) and the Staphylinidae (Coleoptera). Bull. Am. Mus. Nat. Hist. 146(3): 245-303.

Gardner JCM. 1944. New Termitidae from India and Burma (Isoptera). Indian J. Ent. 6: $103-110$.

Gathorne-Hardy FJ. 2004. The termites of Sundaland: A taxonomic review. Sarawak Mus. J. 60(81): 89-133.

Haviland GD. 1898. Observations on termites: with descriptions of new species. J. Linn. Soc. Lond. Zool. 26: 358-422.

Holmgren N. 1910. Das System der Termiten. Zool. Anz. 35: 284-289.

Holmgren N. 1911. Bemerkungen über einige Termiten-Arten. Zool. Anz. 37: 545-553.

Holmgren N. 1912. Die Termiten Japans. Annot. Zool. Jap. 8: 107-136.

Holmgren N. 1913. Termitenstudien. 4. Versuch einer systematischen Monographie der Termiten der orientalischen Region. K. Svenska Vetensk. Akad. Handl. 50(2): $1-276$. 
Holmgren N. 1914. Wissenschaftliche Ergebnisse einer Forschungsreise nach Ostindien, ausgefuhrt im Auftrage der Kgl. Preuss. Akademie der Wissenschaften zu Berlin von H. v. Buttel-Reepen. III. Termiten aus Sumatra, Java, Malacca und Ceylon. Gesammelt von Herrn Prof. Dr. v. Buttel-Reepen in den Jahren 1911-1912. Zool. Jahrb. Abt. Syst. 36(2-3): 229-290.

Huang FS, Li GX, Zhu SM. 1989. The taxonomy and biology of Chinese termites -Isoptera-. Yang Ling, China: Tianze Press.

John O. 1925. Termiten von Ceylon, der Malayaischen Halbinsel, Sumatra, Java und der Aru Onslen. Treubia. 6(3-4): 360-419.

Kemner NA. 1934. Systematische und biologische Studien über die Termiten Javas und Celebes. K. Svenska Vetensk. Akad. Handl. ser. 3. 13(4): 1-241.

Kirton LG, Brown VK. 2003. The taxonomic status of pest species of Coptotermes in Southeast Asia: Resolving the paradox in the pest status of the termites, Coptotermes gestroi, C. havilandi and C. travians (Isoptera: Rhinotermitidae). Sociobiol. 42(1): 43-63.

Kollar V. 1837. Naturgeschichte der Schadlichen Insekten. Verhandl. Landw. Ges. Wien, n.s. 5: 411.

Light SF. 1921. Notes on Philippine termites, II. Philippine J. Sci. 19(1): 23-63.

Oshima M. 1914. Notes on a collection of termites from the East Indian Archipelago. Annot. Zool. Jap. 8: 553-585.

Oshima M. 1920. Philippine termites collected by R. C. McGregor, with descriptions of one new genus and nine new species. Philippine J. Sci. 17(5): 489-512.

Roonwal ML, Maiti PK. 1966. Termites from Indonesia including West Irian. Treubia. 27: $63-140$. 
Silvestri F. 1909. Die Fauna südwest-Australiens, Band.2, Lieferung 17. Isoptera; p. 279-314.

Snyder TE. 1949. Catalog of the termites (Isoptera) of the world. Smiths. Misc. Colls. 112: $1-490$.

Thakur ML, Thakur RK. 1992. Termite fauna of Krakatau and associated islands, Sunda Straits, Indonesia. Treubia. 30: 213-317.

Thapa RS. 1981. Termites of Sabah. Sabah Forest Record. 12: 1-374.

Tho YP. 1992. Malaysia Forest Records, no.36, Termites of Peninsular Malaysia. Malaysia, Kepong: Forest Research Institute.

Tsai PH, Huang FS, Li KS. 1977. Notes on the genus Reticulitermes (Isoptera) from China, with descriptions of new sungenera and new species. Acta Ent. Sinica. 20(4): 465-475.

Wasmann E. 1896. Neue Termitophilen und Termiten aus India. Viaggo di Leonardo Fea in Birmania e Regioni Vicine. Ann. del. Mus. Civ. Stor. Nat. Genova. ser.2. 16(36): 613-630.

Xia KL, He XS. 1986. Study on the genus Coptotermes from China (Isoptera: Rhinotermitidae). Contrib. Shanghai Instit. Ent. 6: 157-182. 
Table and Figures captions

Table 1. List of termite collecting localities.

Figure 1. Map of the termite collecting localities in Thailand.

The numbers 1-25 indicate the localities shown in Table 1. N, North; NE, Northeast; $\mathrm{C}$, Central; E, East; S, South.

Figure 2. Measurements used in this study.

A, head; B, pronotum; C, left mandible; D, postmentum. a, HL; b, bHW; c, mHW; d, PL; e, PW; f, LML; g, DAM1; h, DM1M2; i, PosL; j, PosW.

Figure 3. Soldier of Coptotermes curvignathus Holmgren. A, head, dorsal view; B. head, lateral view; C, pronotum; D, postmentum; E, mandibles. (Scale bar $=0.5 \mathrm{~mm}$ )

Figure 4. Soldier of Coptotermes gestroi (Wasmann). A, head, dorsal view; B. head, lateral view; C, pronotum; D, postmentum; E, mandibles. $($ Scale bar $=0.5 \mathrm{~mm})$

Figure 5. Soldier of Coptotermes kalshoveni Kemner. A, head, dorsal view; B. head, lateral view; C, pronotum; D, postmentum; E, mandibles. $($ Scale bar $=0.5 \mathrm{~mm})$

Figure 6. Soldier of Parrhinotermes buttelreepeni Holmgren. A, head, dorsal view; B, head, lateral view; C, pronotum; D, postmentum; E, antenna; F, mandibles. (Scale bar = $0.5 \mathrm{~mm})$

Figure 7. Soldier of Parrhinotermes microdentiformisoides Thapa. A, head, dorsal view; B, head, lateral view; C, pronotum; D, postmentum; E, antenna; F, mandibles. $($ Scale bar $=0.5 \mathrm{~mm})$

Figure 8. Soldier of Prorhinotermes flavus (Bugnion \& Popoff). A, head, dorsal view; B. head, lateral view; C, pronotum; D, postmentum. (Scale bar $=0.5 \mathrm{~mm})$

Figure 9. Soldier of Reticulitermes assamensis Gardner. A, head, dorsal view; B. head, lateral view; C, pronotum; D, postmentum; E, mandibles. $($ Scale bar $=0.5 \mathrm{~mm})$ 
Figure 10. Soldier of Schedorhinotermes malaccensis (Holmgren). A, head of major soldier, dorsal view; B, head of major soldier, lateral view; $\mathrm{C}$, pronotum of major soldier; D, postmentum of major soldier; E, mandibles of major soldier; F, head of minor soldier, dorsal view; $G$, head of minor soldier, lateral view; $H$, pronotum of minor soldier; I, postmentum of minor soldier; J, mandibles of minor soldier. (Scale bar $=0.5$ $\mathrm{mm})$

Figure 11. Soldier of Schedorhinotermes medioobscurus (Holmgren). A, head of major soldier, dorsal view; B, head of major soldier, lateral view; C, pronotum of major soldier; D, postmentum of major soldier; E, mandibles of major soldier; F, head of minor soldier, dorsal view; $\mathrm{G}$, head of minor soldier, lateral view; $\mathrm{H}$, pronotum of minor soldier; I, postmentum of minor soldier; J, mandibles of minor soldier. (Scale bar $=0.5$ $\mathrm{mm})$

Figure 12. Soldier of Schedorhinotermes rectangularis Ahmad. A, head of major soldier, dorsal view; B, head of major soldier, lateral view; C, pronotum of major soldier; D, postmentum of major soldier; E, mandibles of major soldier; $\mathrm{F}$, head of minor soldier, dorsal view; G, head of minor soldier, lateral view; H, pronotum of minor soldier; I, postmentum of minor soldier; J, mandibles of minor soldier. (Scale bar $=0.5 \mathrm{~mm}$ )

Figure 13. Distribution of Coptotermes and Reticulitermes in Thailand. A, Coptotermes curvignathus; B, C. gestroi; C, C. kalshoveni; D, C. premrasmii; E, Reticulitermes assamensis. (Record of C. premrasmii is from original description.)

Figure 14. Distribution of Parrhinotermes, Prorhinotermes and Schedorhinotermes in Thailand. A, Parrhinotermes buttelreepeni; B, P. microdentiformisoides; C, Prorhinotermes flavus; D, Schedorhinotermes malaccensis; E, S. medioobscurus; F, S. rectangularis. 


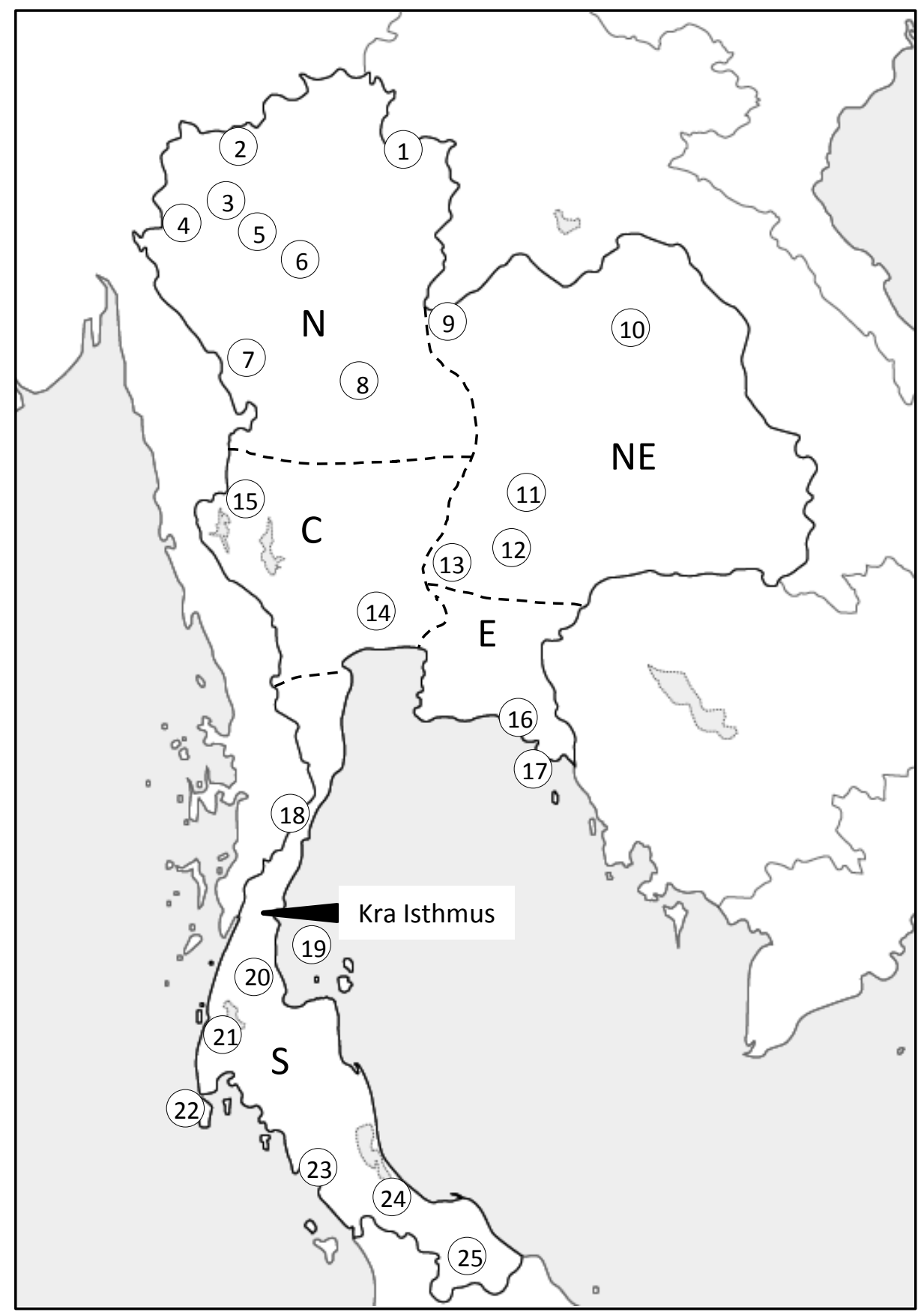

FIGURE 1. Map of the termite collecting localities in Thailand.

The numbers 1-25 indicate the localities shown in Table 1. N, North; NE, Northeast; C, Central; E, East; S, South. 


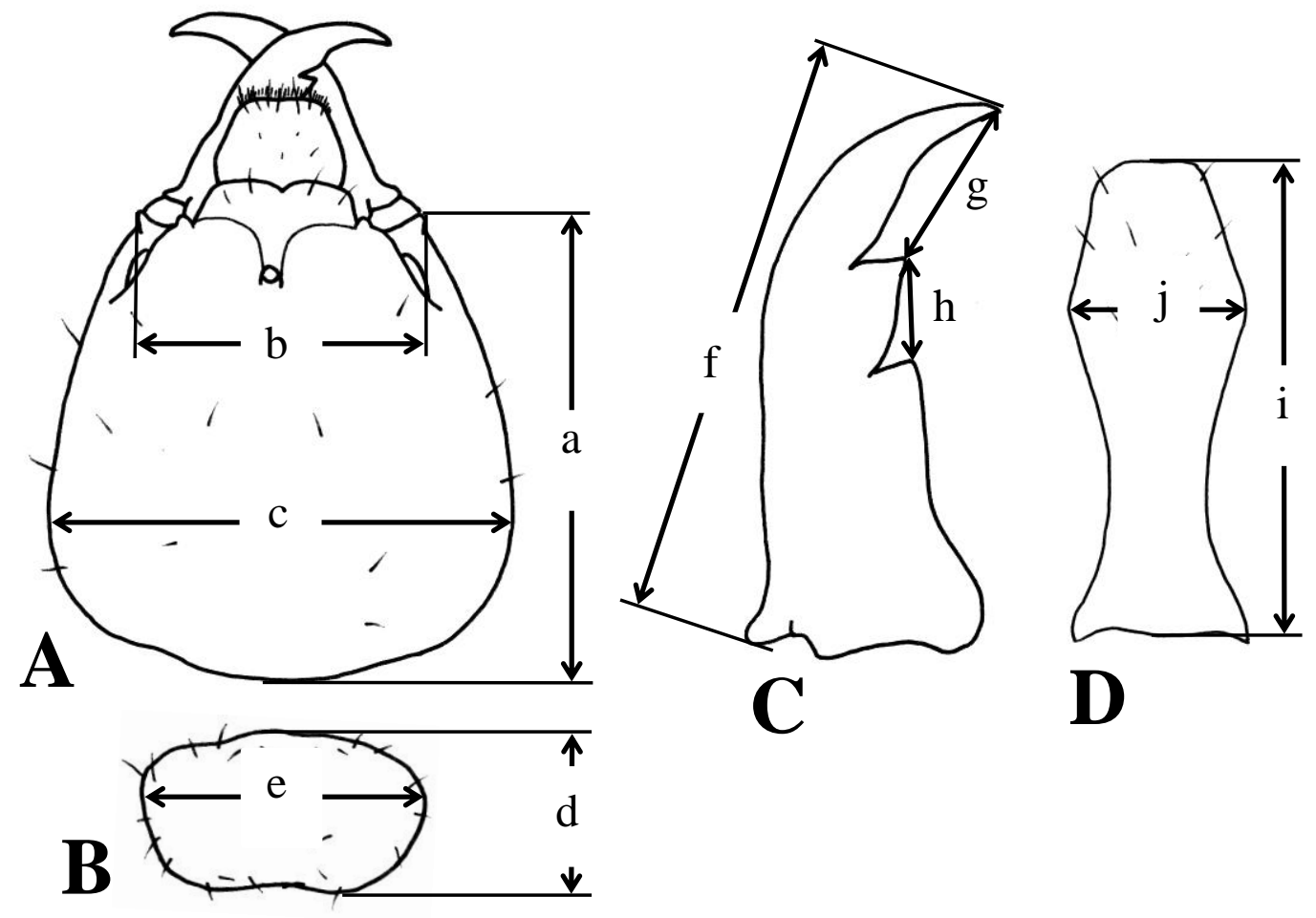

FIGURE 2. Measurements used in this study.

A, head; B, pronotum; C, left mandible; D, postmentum. a, HL; b, bHW; c, mHW; d, PL; e, PW; f, LML; g, DAM1; h, DM1M2; i, PosL; j, PosW. 


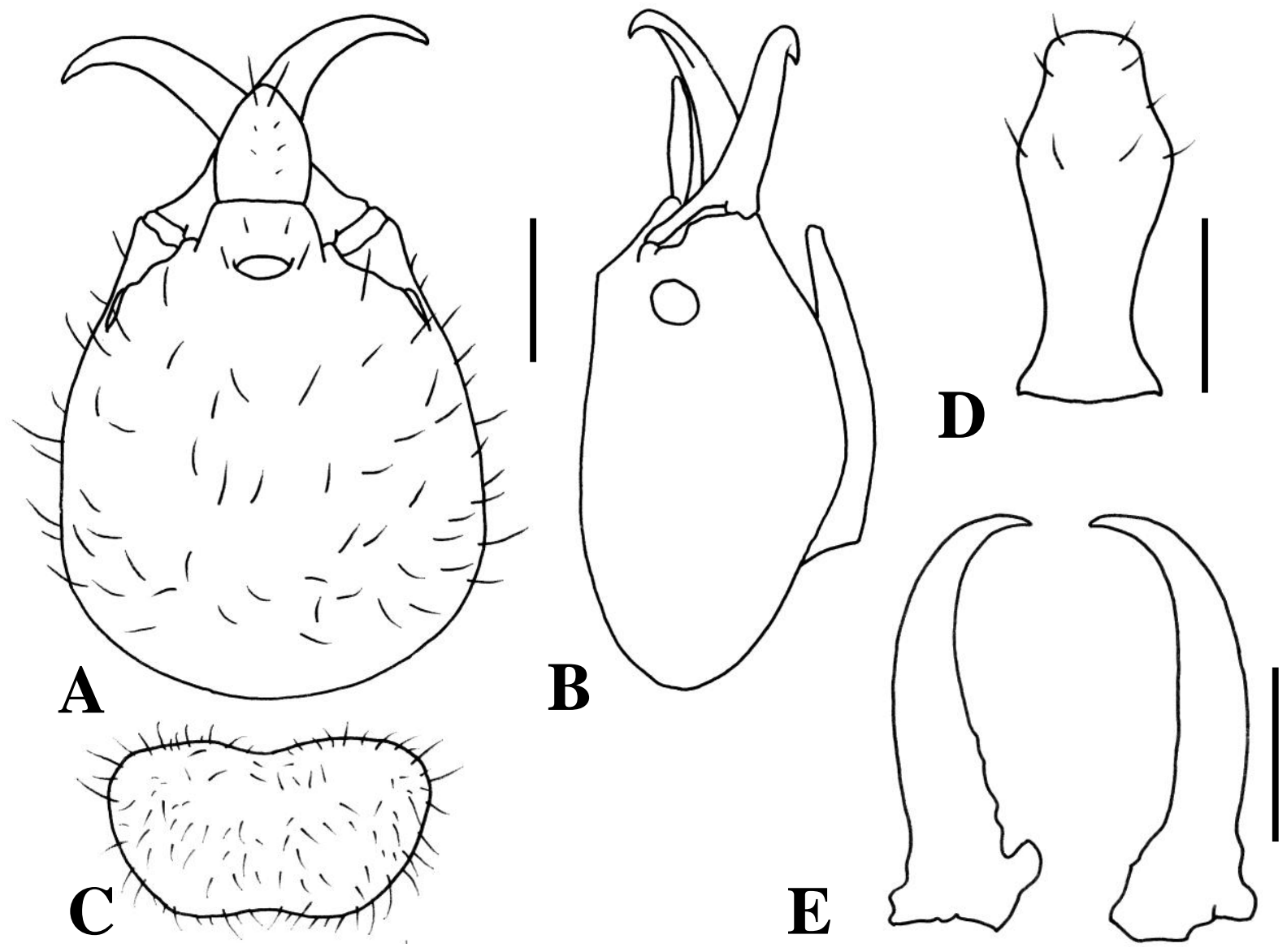

FIGURE 3. Soldier of Coptotermes curvignathus Holmgren. A, head, dorsal view; B. head, lateral view; $\mathrm{C}$, pronotum; D, postmentum; E, mandibles. (Scale bar $=0.5 \mathrm{~mm}$ ) 


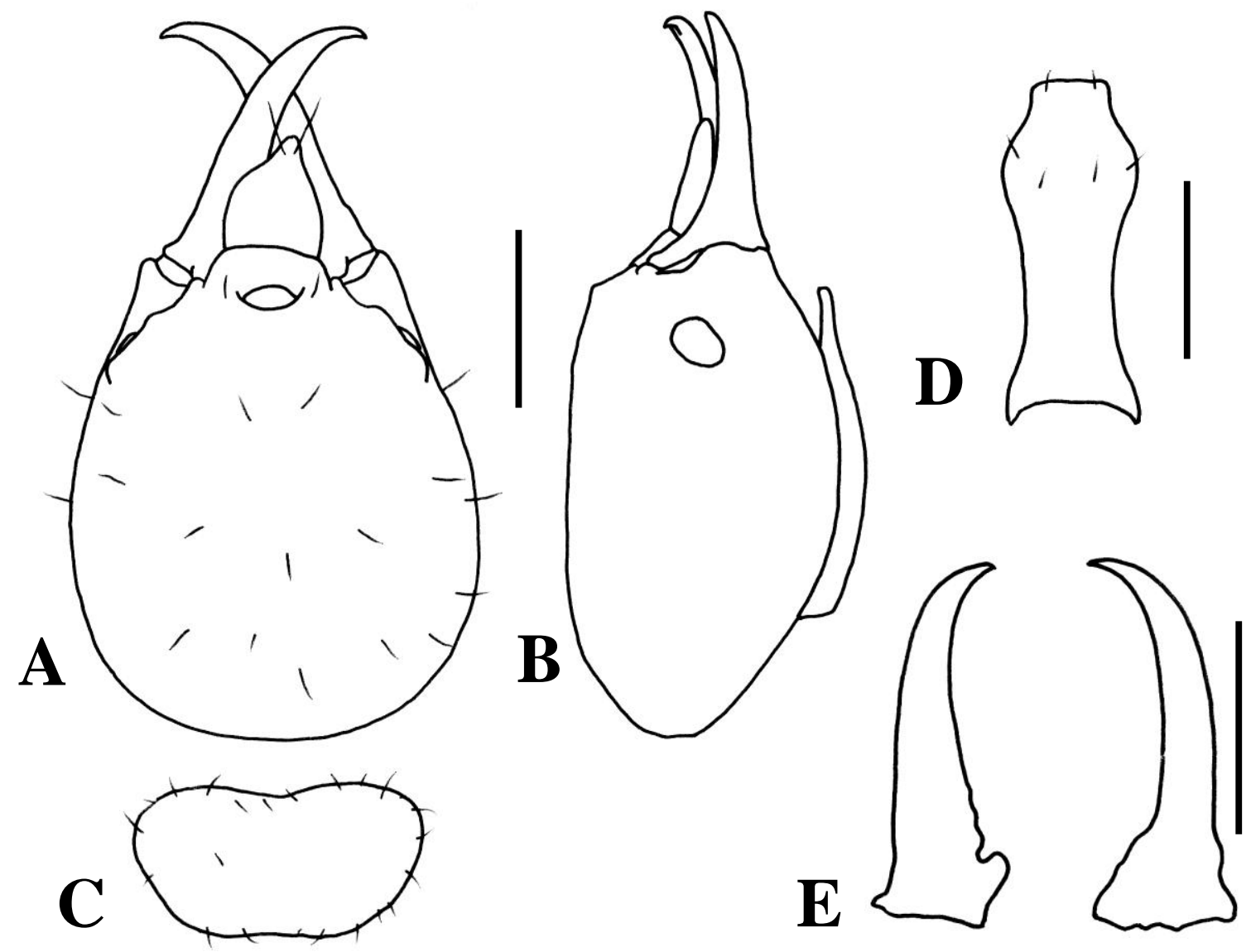

FIGURE 4. Soldier of Coptotermes gestroi (Wasmann). A, head, dorsal view; B. head, lateral view; C, pronotum; $\mathrm{D}$, postmentum; $\mathrm{E}$, mandibles. (Scale bar $=0.5 \mathrm{~mm}$ ) 


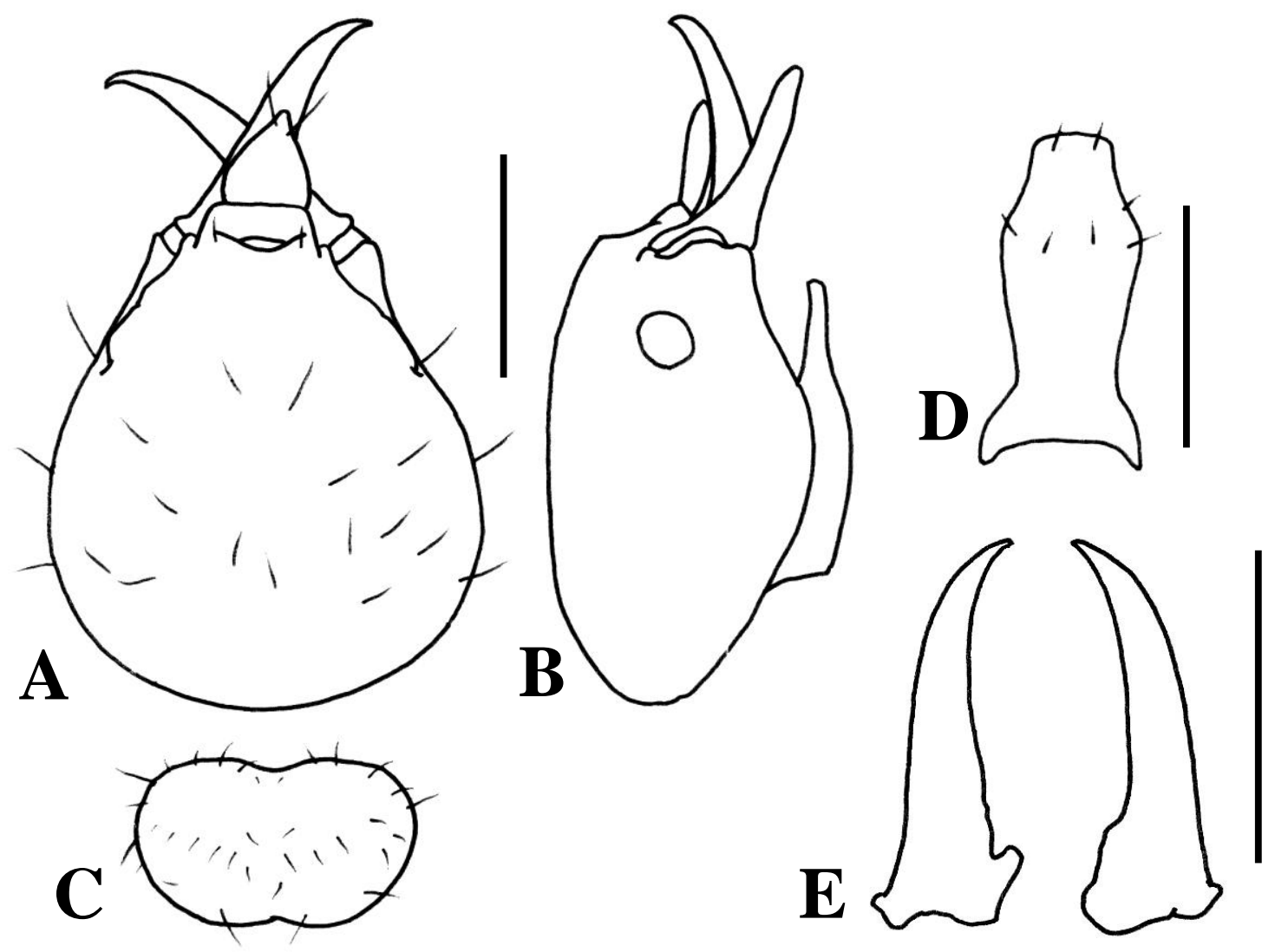

FIGURE 5. Soldier of Coptotermes kalshoveni Kemner. A, head, dorsal view; B. head, lateral view; C, pronotum; D, postmentum; $E$, mandibles. (Scale bar $=0.5 \mathrm{~mm}$ ) 


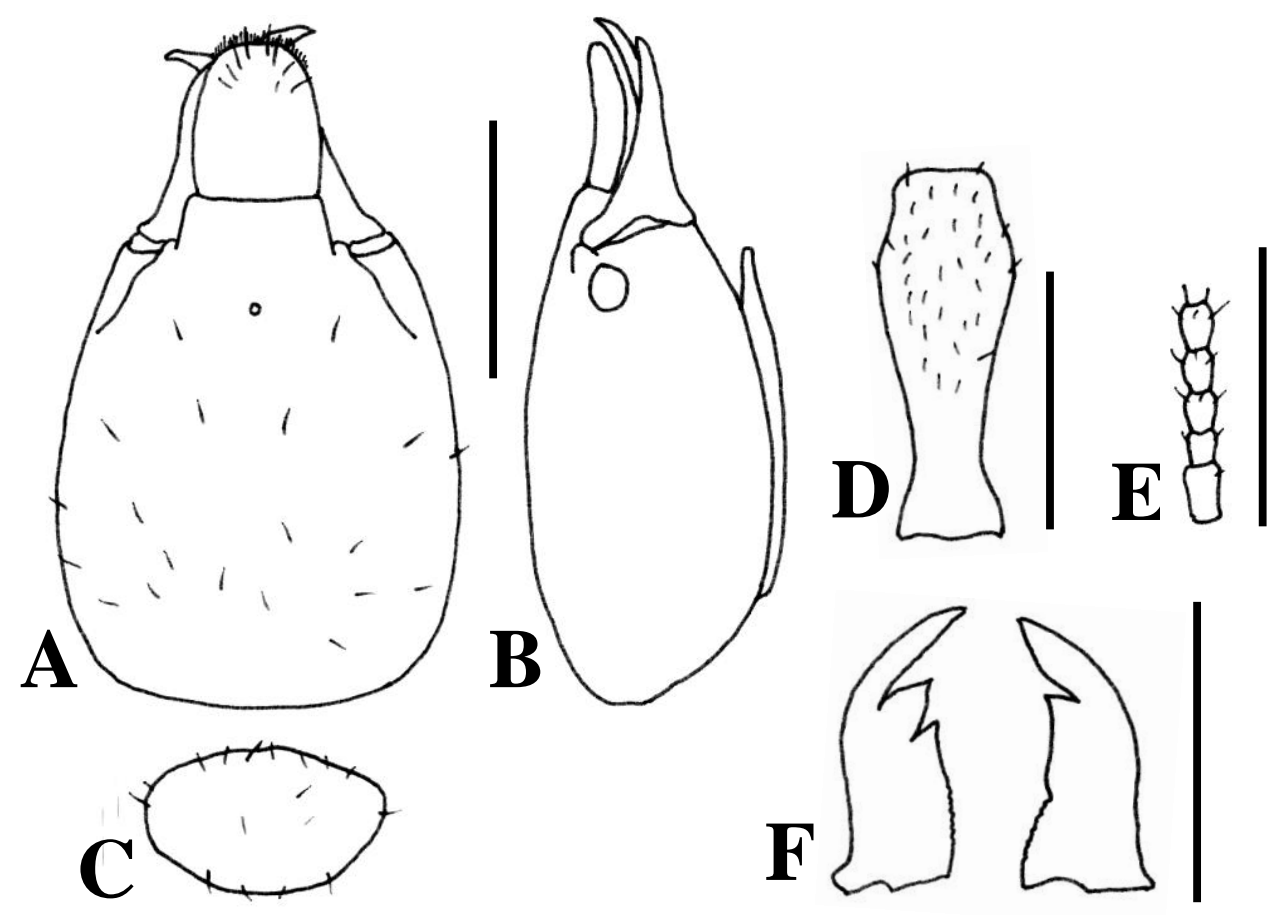

FIGURE 6. Soldier of Parrhinotermes buttelreepeni Holmgren. A, head, dorsal view; B, head, lateral view; C, pronotum; D, postmentum; E, antenna; F, mandibles. (Scale bar $=0.5 \mathrm{~mm}$ ) 


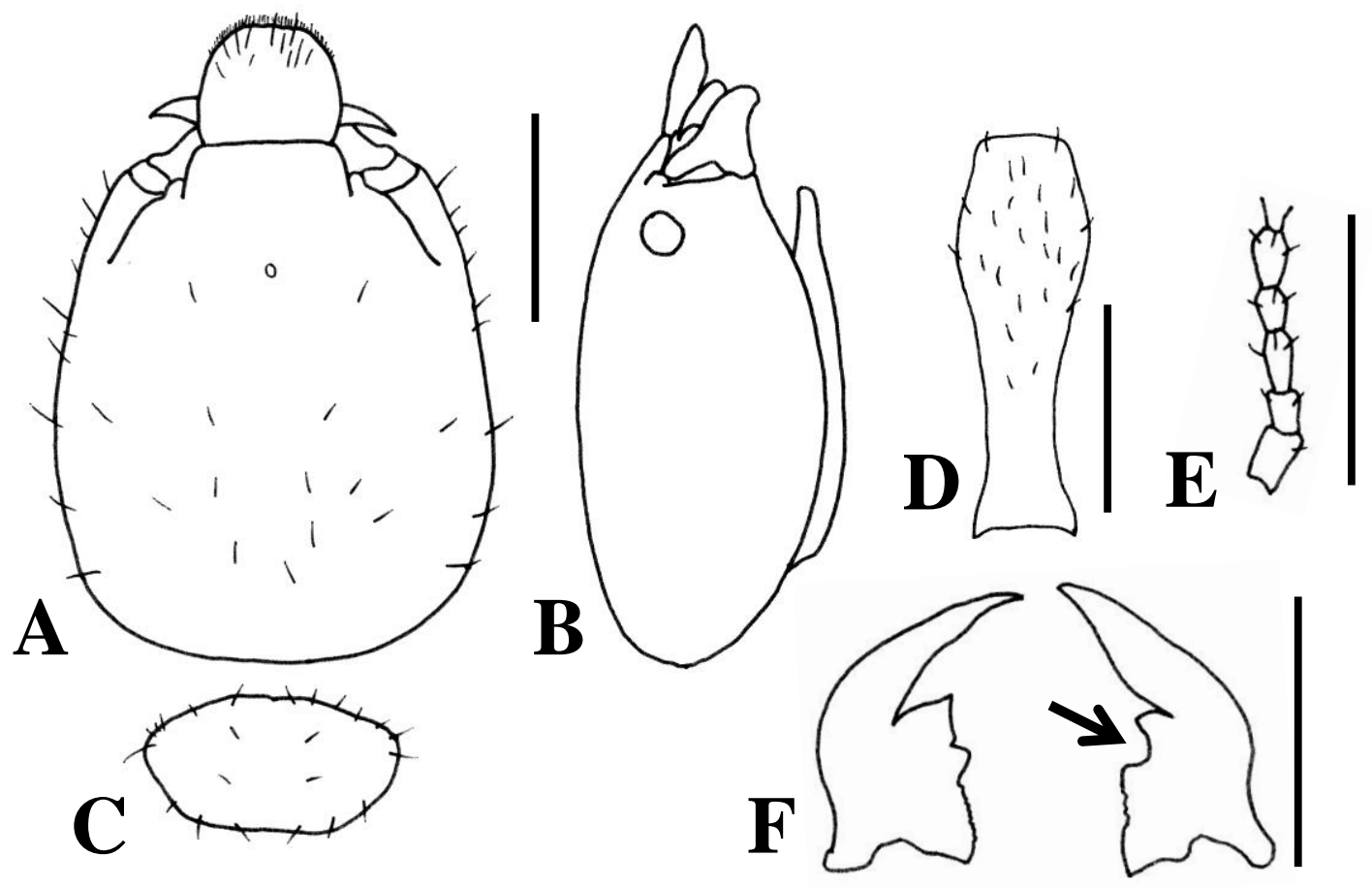

FIGURE 7. Soldier of Parrhinotermes microdentiformisoides Thapa. A, head, dorsal view; B, head, lateral view; C, pronotum; D, postmentum; $E$, antenna; $F$, mandibles. (Scale bar $=0.5 \mathrm{~mm}$ ) 


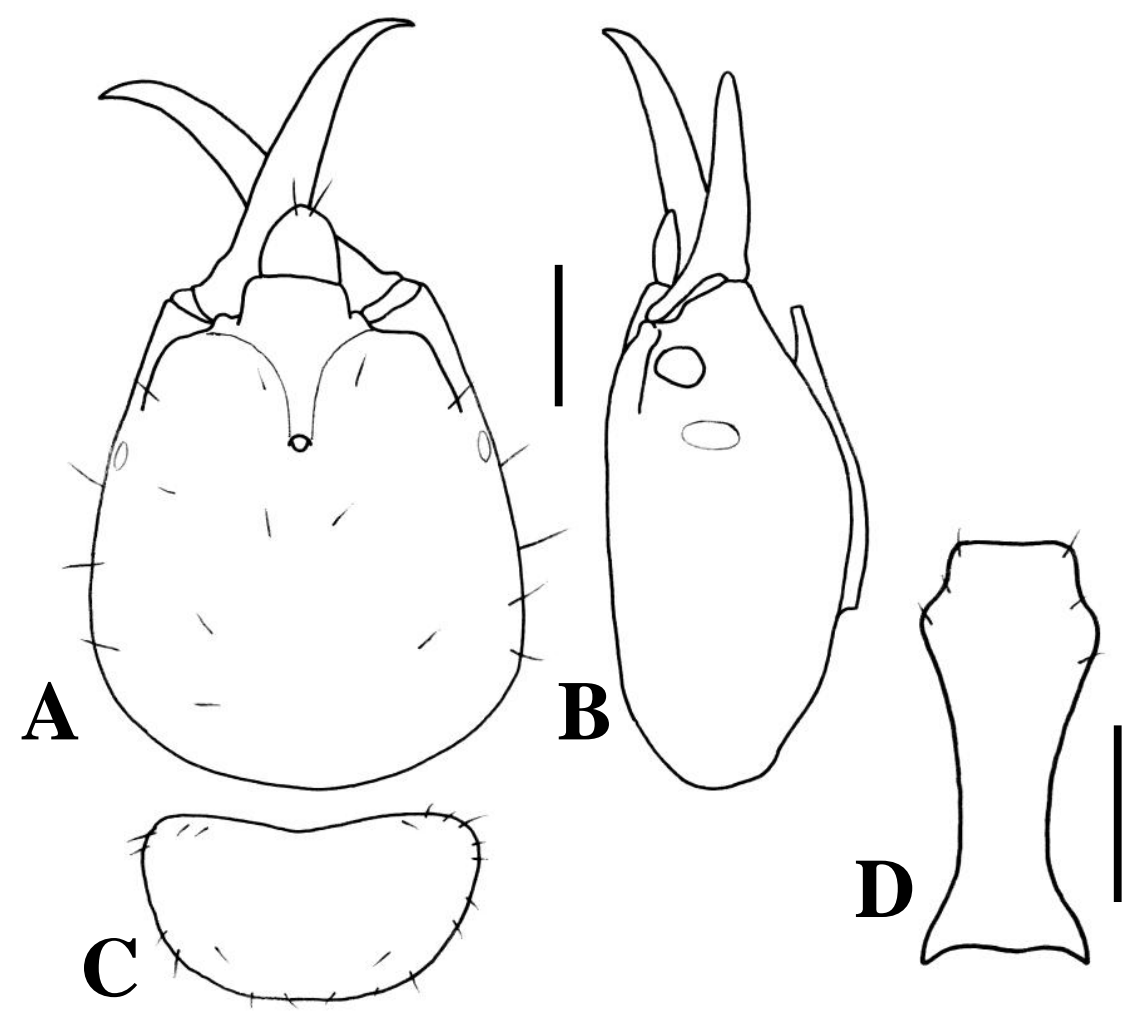

FIGURE 8. Soldier of Prorhinotermes flavus (Bugnion \& Popoff). A, head, dorsal view; B. head, lateral view; C, pronotum; D, postmentum. (Scale bar $=0.5 \mathrm{~mm}$ ) 


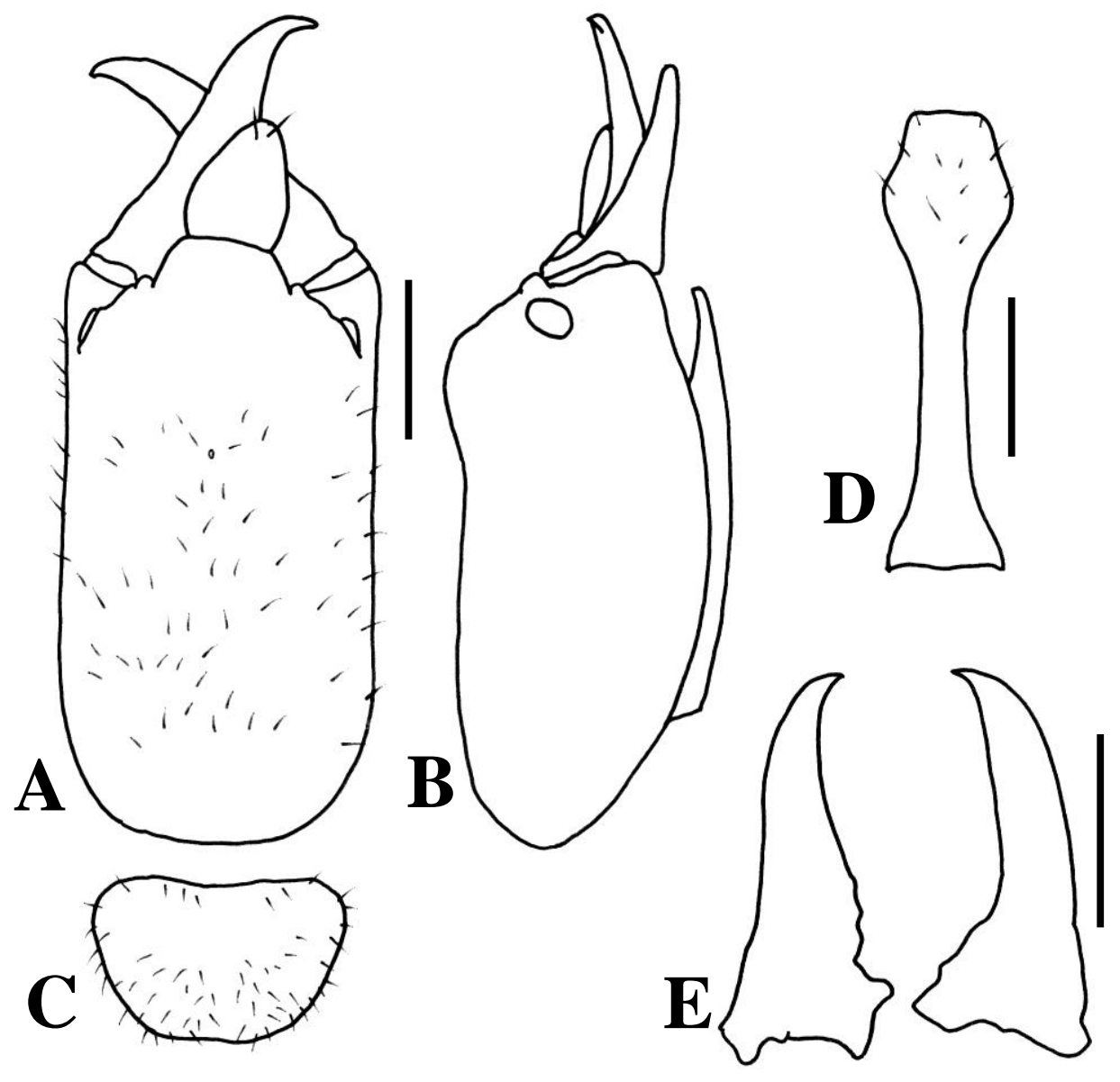

FIGURE 9. Soldier of Reticulitermes assamensis Gardner. A, head, dorsal view; B. head, lateral view; $\mathrm{C}$, pronotum; D, postmentum; $\mathrm{E}$, mandibles. (Scale bar $=0.5 \mathrm{~mm}$ ) 


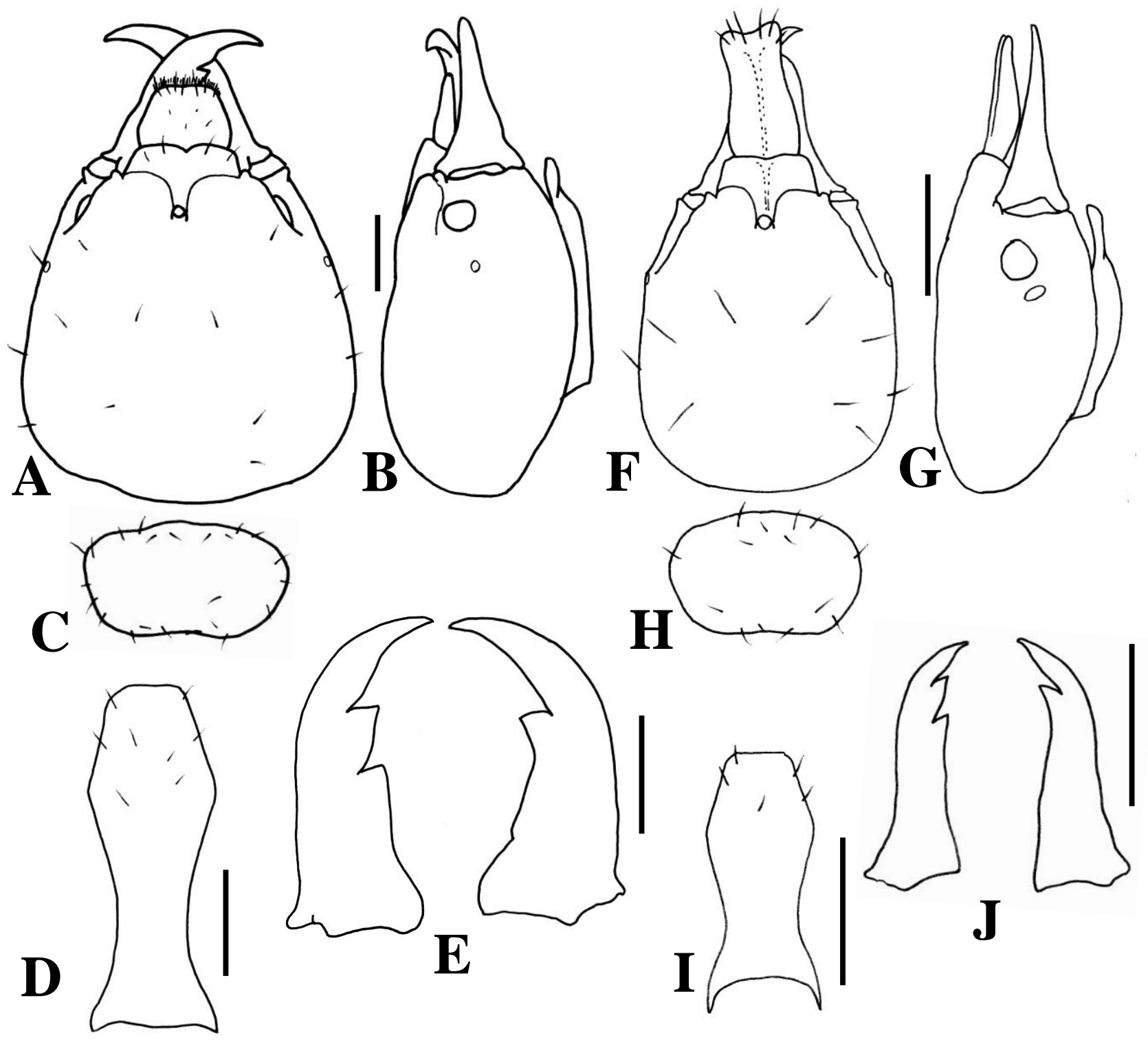

FIGURE 10. Soldier of Schedorhinotermes malaccensis (Holmgren). A, head of major soldier, dorsal view; $B$, head of major soldier, lateral view; $C$, pronotum of major soldier; $D$, postmentum of major soldier; E, mandibles of major soldier; F, head of minor soldier, dorsal view; G, head of minor soldier, lateral view; $\mathrm{H}$, pronotum of minor soldier; I, postmentum of minor soldier; J, mandibles of minor soldier. $($ Scale bar $=0.5 \mathrm{~mm})$ 


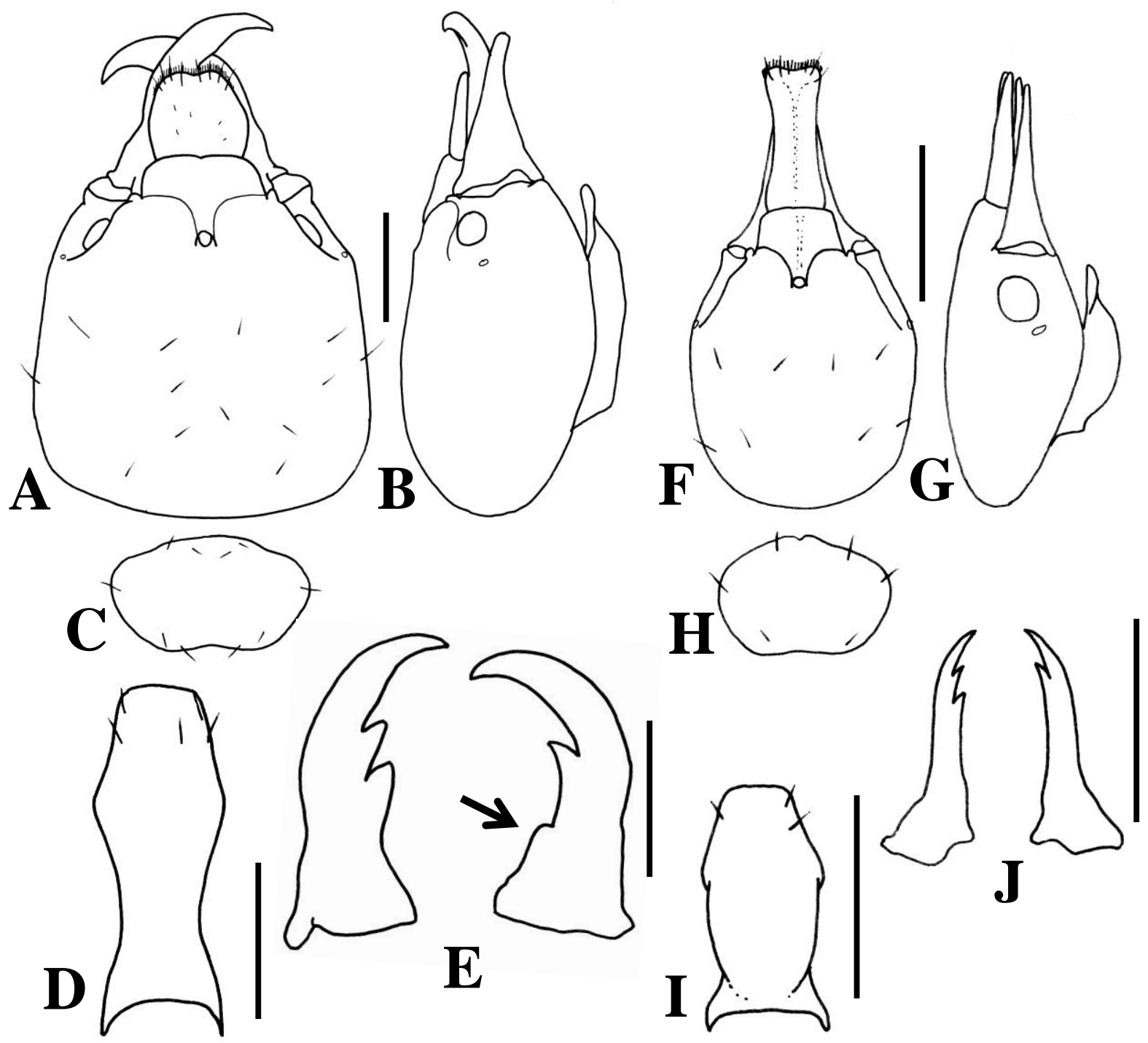

FIGURE 11. Soldier of Schedorhinotermes medioobscurus (Holmgren). A, head of major soldier, dorsal view; B, head of major soldier, lateral view; C, pronotum of major soldier; D, postmentum of major soldier; E, mandibles of major soldier; F, head of minor soldier, dorsal view; $G$, head of minor soldier, lateral view; H, pronotum of minor soldier; I, postmentum of minor soldier; J, mandibles of minor soldier. (Scale bar $=0.5 \mathrm{~mm}$ ) 


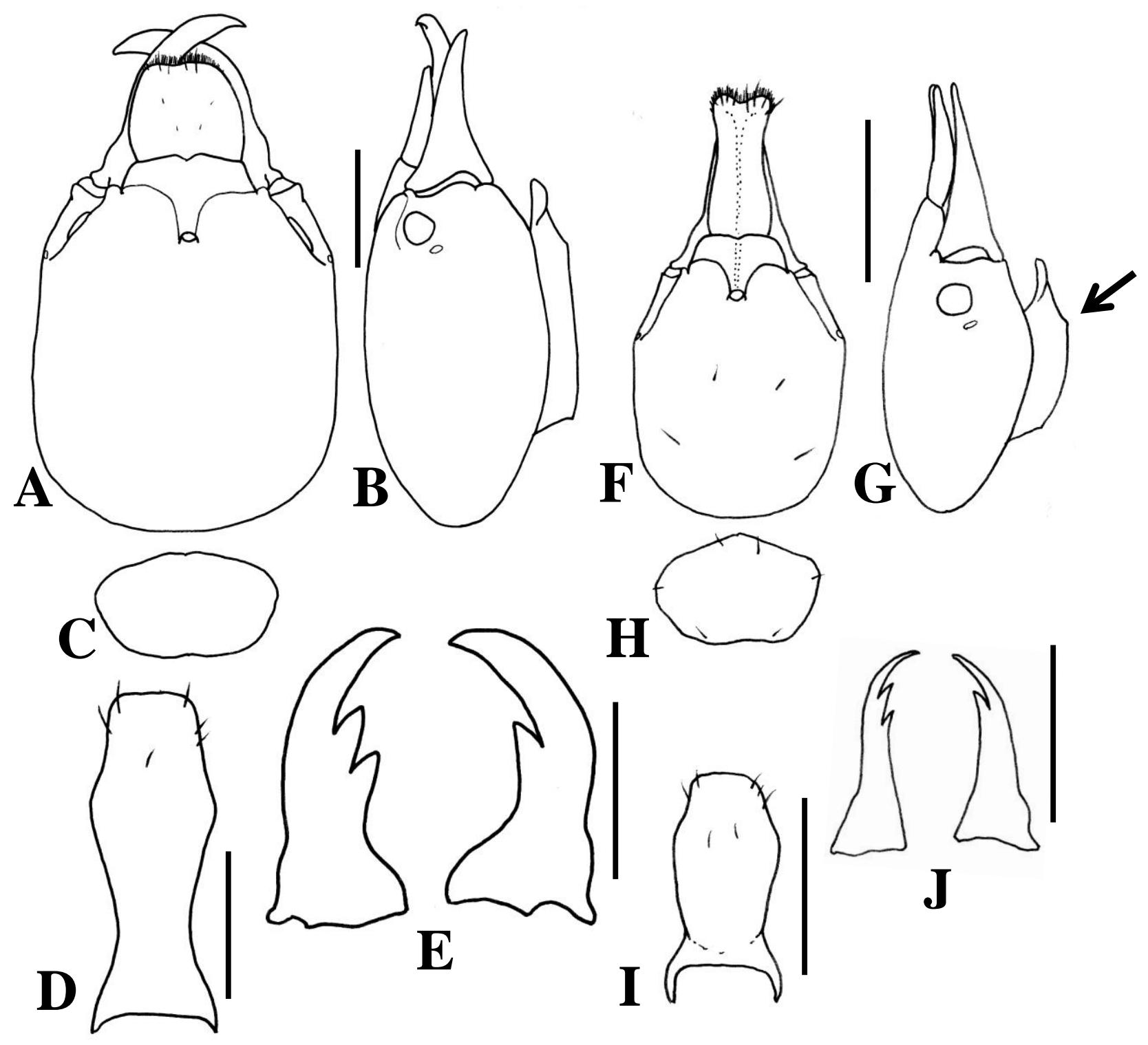

FIGURE 12. Soldier of Schedorhinotermes rectangularis Ahmad. A, head of major soldier, dorsal view; $B$, head of major soldier, lateral view; C, pronotum of major soldier; D, postmentum of major soldier; $E$, mandibles of major soldier; $F$, head of minor soldier, dorsal view; $G$, head of minor soldier, lateral view; $\mathrm{H}$, pronotum of minor soldier; I, postmentum of minor soldier; J, mandibles of minor soldier. (Scale bar $=0.5 \mathrm{~mm}$ ) 

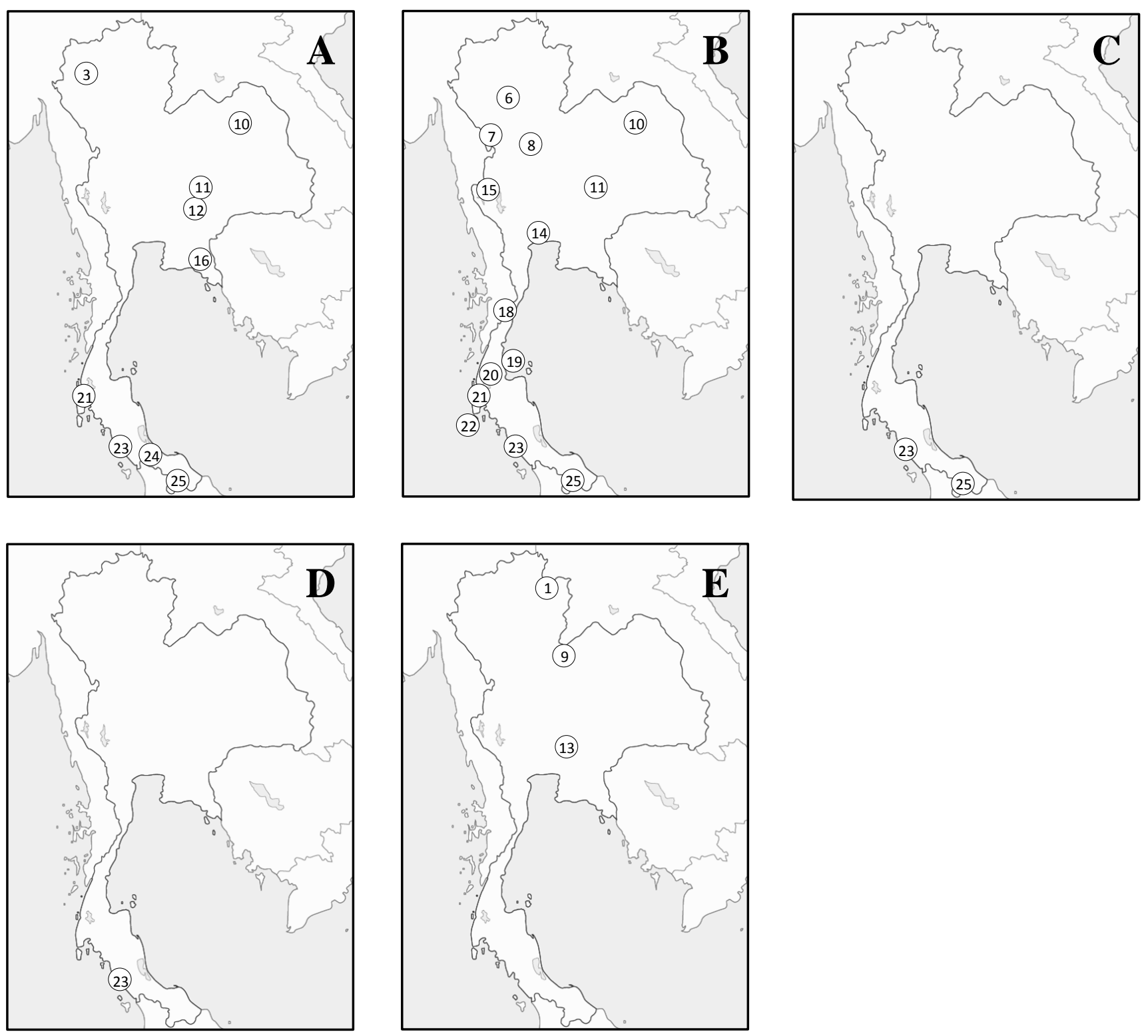

FIGURE 13. Distribution of Coptotermes and Reticulitermes in Thailand. A, Coptotermes curvignathus; B, C. gestroi; C, C. kalshoveni; D, C. premrasmii; E, Reticulitermes assamensis. (Record of $C$. premrasmii is from original description.) 

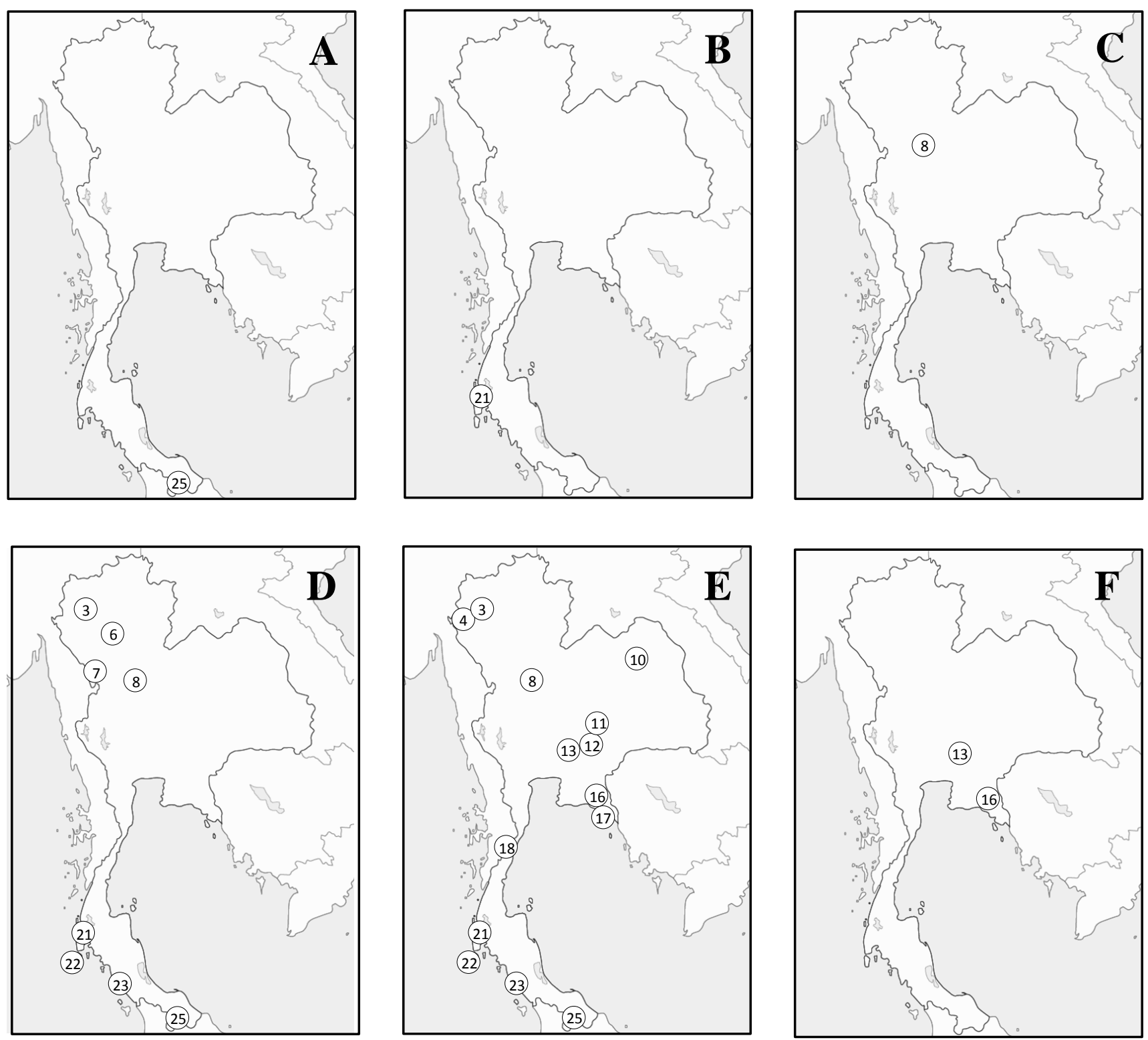

FIGURE 14. Distribution of Parrhinotermes, Prorhinotermes and Schedorhinotermes in Thailand. A, Parrhinotermes buttelreepeni; B, P. microdentiformisoides; C, Prorhinotermes flavus; D, Schedorhinotermes malaccensis; E, S. medioobscurus; F, S. rectangularis. 